\title{
The net effect of advice on strategy-proof mechanisms: an experiment for the Vickrey auction
}

\author{
Takehito Masuda $^{1} \cdot$ Ryo Mikami $^{2} \cdot$ Toyotaka Sakai $^{3} \cdot$ Shigehiro Serizawa $^{2}$. \\ Takuma Wakayama4 ${ }^{4}$
}

Received: 12 November 2019 / Revised: 5 October 2021 / Accepted: 5 October 2021 /

Published online: 2 February 2022

(c) The Author(s) 2022

\begin{abstract}
We conduct laboratory experiments for the multi-unit Vickrey auction with and without advice to subjects on strategy-proofness. The rate of truth-telling among the subjects without advice stays at $20 \%$, whereas the rate increases to $47 \%$ among those who have received advice. By conducting similar experiments for the pay-your-bid auction, which is not strategy-proof, we confirm that the increase in truth-telling is due significantly to the net advice effect (i.e., the effect beyond the so-called experimenter demand effect). Moreover, we find that providing advice improves efficiency in the Vickrey auction, particularly in the early periods, when the subjects are less experienced. In general, subjects tend to overbid in Vickrey auction experiments. Our results indicate the possibility that providing simple advice decreases such overbidding by promoting a better understanding of the strategy-proofness of the Vickrey auction. Strategy-proof mechanisms are sometimes criticized because players often fail to recognize the benefit of telling the truth. However, our observations show that introducing advice on the property of strategy-proofness helps them behave "correctly."
\end{abstract}

Keywords Advice effect · Strategy-proofness · Vickrey auction · Pay-your-bid auction $\cdot$ Ausubel auction $\cdot$ Market design

JEL Classification D44 · D71 · D61 · D82

A version of this paper was previously circulated under the title "A strategy-proof mechanism should be announced strategy-proof: An experiment for the Vickrey auction."

Takuma Wakayama

wakayama@econ.ryukoku.ac.jp

Extended author information available on the last page of the article 


\section{Introduction}

\subsection{Motivation and outline}

The technology for the design of economic mechanisms has grown rapidly in the last few decades. Practical applications of economic mechanisms now include spectrum auctions (Milgrom 2000), school choice (Abdulkadiroğlu and Sönmez 2003), and kidney exchange (Roth et al. 2004), among many others. A preferred property of such mechanisms is strategy-proofness, which ensures that truthfully reporting his/ her own type is always a weakly dominant strategy for every participant. Provided that a strategy-proof mechanism is employed, everyone has an incentive to report his/her true type to ensure that a social goal is realized through the collection of accurate information.

However, in the experimental literature on strategy-proof mechanisms, it has often been observed that telling the truth is far from universal (e.g., Attiyeh et al. (2000), Kawagoe and Mori (2001), Cason et al. (2006), and Chen and Sönmez (2006)). ${ }^{1}$ These observations have been considered an anomaly to the theory, encouraging skepticism of the practical performance of strategy-proof mechanisms. A prominent example is the Vickrey auction (Vickrey 1961), under which many experimental studies have observed overbidding. ${ }^{2}$ However, this does not imply that the strategy-proofness of the Vickrey auction is useless in reality. Simply put, it suggests the necessity of developing some device that enables strategy-proofness to work, making the Vickrey auction useful in real-life applications.

For an average person, it is not easy to realize that the Vickrey auction is strategyproof. ${ }^{3}$ That is, the Vickrey auction does not exhibit the expected performance by merely explaining the auction rule to participants. A simple method to address this issue is to announce the strategy-proofness of the Vickrey auction to users, which is what we shall attempt in this experimental research.

In our experiment, we provide a piece of simple advice on the strategy-proofness of the Vickrey auction to the subjects and examine its effect on the subjects' behavior and the efficiency of outcomes. Our experiment focuses on a case where multiple

\footnotetext{
1 Velez and Brown (2020) study the observations in the experimental literature on strategy-proof mechanisms from a different perspective. They identify the conditions under which the untruthful behavior is "empirically" plausible.

2 Several experimental studies report that most subjects do not reveal their true type in the Vickrey auction even in the single-unit case. Kagel and Levin (1993) find that the rate of sincere bidding is approximately $27 \%$ of all bids. Garratt et al. (2012) report that despite the fact that the subjects are familiar with bidding in eBay auctions, approximately four out of five subjects fail to bid sincerely. Manelli et al. (2006) and Kagel and Levin (2009) observe that subjects in a Vickrey auction experiment tend to overbid, compared with those in the Ausubel auction (Ausubel 2004), which is a dynamic counterpart of the Vickrey auction. See Kagel and Levin (2016) for a survey on the experimental results of the Vickrey auction.

${ }^{3}$ Hassidim et al. (2017) provide possible explanations as to why individuals do not report their true preferences under the deferred acceptance mechanism, which is a well-known strategy-proof mechanism in the context of two-sided matching-both in the field and in the lab. They cite "failure to identify the dominant strategy" as one of the explanations.
} 
units of identical objects are to be sold under the Vickrey auction. We observe that, although the rate of sincere bidding is $20.6 \%$ without advice, it increases to $46.9 \%$ once subjects are advised regarding the strategy-proofness of the Vickrey auction.

One might suspect that this increase is due to the so-called experimenter demand effect (Zizzo 2009). Thus, we attempt to detect whether an effect of advice exists beyond the experimenter demand effect, which we call the net advice effect. To this end, we conducted similar experiments for the pay-your-bid auction, which is not strategy-proof. ${ }^{4}$ We used the same advice across auction rules to cause similar experimenter demand effects in both auctions. ${ }^{5}$ The comparison results for the payyour-bid auction reveal that the Vickrey auction has a large net advice effect. Moreover, for the Vickrey auction, the effect of the advice is stronger for the subjects with a perfect score in a quiz on the auction rules than for the other subjects. ${ }^{6}$

In the literature on auction theory, overbidding in the Vickrey/second price auction has been attributed to various factors such as the joy of winning (Cooper and Fang 2008), the presence of a cognitive limit on contingent reasoning ( $\mathrm{Li} 2017$ ), the underestimation of possible losses (Georganas et al. 2017), and so on. However, our results show the possibility that merely providing a piece of simple advice decreases overbidding by promoting a better understanding of the strategy-proofness of the Vickrey auction. Our experimental results suggest that, before operating strategyproof mechanisms, explaining the property of strategy-proofness helps those who are unaware of its property to behave "correctly."

Finally, we conducted an experiment to test the effect of advice for the Ausubel auction (Ausubel 2004), which is known as a dynamic counterpart of the Vickrey auction. ${ }^{7}$ This auction rule is not strategy-proof because in it, sincere bidding, where bidders may reduce their demand for units at prices equal to their valuations for these units, is not a weakly dominant strategy. Meanwhile, it is well known that in the Ausubel auction, sincere bidding is an ex-post equilibrium (Ausubel 2004; Okamoto 2018). Thus, based on our experimental results above, one would expect that providing simple advice on this property would increase the rate of sincere bidding in the Ausubel auction, similar to that in the Vickrey auction. Although the Ausubel auction is a dynamic mechanism, we set the instruction and advice in the Ausubel auction treatment as similar to the main experiments to the extent possible, but without making deception. We find that the advice effect also exists in the Ausubel auction. This finding suggests that providing "appropriate" advice could serve as a tool to improve the performance of even non-strategy-proof mechanisms.

\footnotetext{
4 The pay-your-bid auction is used by many countries in practical Treasury bond allocations. See Brenner et al. (2009) and Marszalec (2017) for more details.

5 To avoid deception, we added a careful note to the advice. See Sect. 2.2 for more details.

${ }^{6}$ Guillen and Hakimov (2017) analyze the effect of quiz scores on the rate of truth-telling in a strategyproof matching mechanism experiment. Similarly, Hanaki et al. (2016) find that subjects with higher cognitive ability are more likely to perform one step of elimination of dominated strategies.

7 We thank an anonymous referee for suggesting this experiment.
} 


\subsection{Related literature}

The effect of providing advice on strategy-proof mechanisms has recently been investigated by several authors (Guillen and Hing 2014; Ding and Schotter 2019). In these studies, two-sided matching models are used to verify whether providing advice will affect the rate of truth-telling. A closely related work by Guillen and Hakimov (2018) finds that announcing the strategy-proofness of strategy-proof matching mechanisms increases the rate of truth-telling, while providing a detailed explanation of the mechanism has the opposite effect. ${ }^{8}$ These results suggest that advice helps participants confirm individual optimality of truth-telling. To the best of our knowledge, our study is the first to test the role of advice in the literature of auction studies. $^{9}$

To improve individuals' understanding on incentive properties, Saijo et al. (2007) and $\mathrm{Li} \mathrm{(2017)} \mathrm{attempt} \mathrm{to} \mathrm{strengthen} \mathrm{the} \mathrm{notion} \mathrm{of} \mathrm{strategy-proofness.} \mathrm{Saijo} \mathrm{et} \mathrm{al.}$ (2007) emphasize that, even if a mechanism is strategy-proof, it often admits the presence of an inefficient Nash equilibrium composed of mis-reporting. Saijo et al. (2007) strengthen strategy-proofness to "secure implementability" by additionally requiring that no Nash equilibrium achieves an outcome that is not the "true" outcome. An experimental study by Cason et al. (2006) compares bidding behavior under a securely implementable (and so strategy-proof) mechanism and that of other strategy-proof mechanisms. They observe that the rate of truth-telling in the former is higher than in the latter.

$\mathrm{Li}$ (2017) proposes a stronger version of strategy-proofness called "obvious strategy-proofness" that could be applied to dynamic mechanisms, such as ascending auctions or matching algorithms. In a problem where a single object is auctioned, the ascending auction is obviously strategy-proof, but the Vickrey auction is not. In an experiment where a single object is auctioned, $\mathrm{Li}$ observes that the ratio of dominant strategies played by subjects is significantly higher in the ascending clock auction than in the Vickrey auction.

However, given that the class of strategy-proof mechanisms is already narrow (e.g., Holmström (1979)), strengthening strategy-proofness severely restricts the admissible class of mechanisms. Conversely, our approach of providing advice can be applied to any strategy-proof mechanism in any environment. The Vickrey auction is neither securely implementable nor obviously strategy-proof, but providing advice drastically improves its truth-telling performance.

\footnotetext{
${ }^{8}$ Guillen and Hakimov (2018) consider a top-down advice (e.g., advice given by the mechanism administrator). Several studies examine whether the source of advice affects the truth-telling behavior: advice given to children by their parents (Ding and Schotter 2019), peer information sharing in networks (Ding and Schotter 2017), and third-party advice such as websites (Guillen and Hing 2014).

${ }^{9}$ Shogren et al. (2001) conduct a Vickrey auction experiment under the condition where subjects are informed of the strategy-proofness of the Vickrey auction. However, they do not test the effect of the advice, that is, they do not conduct a Vickrey auction experiment without advice. In addition, in some experimental studies that aim to elicit real valuations for items through incentive-compatible mechanisms such as the Vickrey auction, the experimental instructions explicitly inform subjects that truth-telling is the best strategy (e.g., Grether and Plott (1979) and List (2001)). However, these studies do not test whether providing such information affects the rate of truth-telling.
} 


\subsection{Organization}

The remainder of the paper is organized as follows. Section 2 describes the theoretical background and our experimental design and proposes several hypotheses. Section 3 presents our experimental results. Section 4 describes the Ausubel auction treatment in detail and discusses our experimental results on the Ausubel auction. Finally, Sect. 5 provides the concluding remarks.

\section{Experimental design}

\subsection{Theoretical considerations}

There are three bidders, $\{1,2,3\}$, and two indivisible, identical objects to be auctioned. Each bidder is admitted to demand two units. Bidder $i$ 's valuation for the objects is denoted by $v_{i}=\left(v_{i}^{1}, v_{i}^{2}\right)$, where $v_{i}^{1} \geq v_{i}^{2} \geq 0$ and $v_{i}^{j}$ denotes the value that bidder $i$ assigns to the $j$-th unit. Given any $v_{i}$, bidder $i$ 's utility of obtaining $k$ units of objects and paying $m_{i}$ units of money is: ${ }^{10}$

$$
U\left(k, m_{i} ; v_{i}\right) \equiv \begin{cases}v_{i}^{1}+v_{i}^{2}-m_{i} & \text { if } k=2 \\ v_{i}^{1}-m_{i} & \text { if } k=1 \\ -m_{i} & \text { if } k=0\end{cases}
$$

A list $v=\left(v_{1}, v_{2}, v_{3}\right)$ is a valuation profile. A bid submitted by bidder $i$ is denoted by $b_{i}=\left(b_{i}^{1}, b_{i}^{2}\right)$, where $b_{i}^{1} \geq b_{i}^{2} \geq 0$ and $b_{i}^{j}$ denotes the bid of bidder $i$ for the $j$-th unit. Let $b=\left(b_{1}, b_{2}, b_{3}\right)$ be a bid profile.

An assignment function is a function $d=\left(d_{1}, d_{2}, d_{3}\right)$ that specifies, for each bid profile $b$, the number of the objects bidder $i$ obtains $d_{i}(b) \in\{0,1,2\}$ under the following resource constraint: $d_{1}(b)+d_{2}(b)+d_{3}(b)=2$. A payment function is a function $m=\left(m_{1}, m_{2}, m_{3}\right)$ that specifies, for each bid profile $b$, the amount of money bidder $i$ pays $m_{i}(b)$. An rule is a pair of assignment and payment functions $(d, m)$.

We are interested in rules in which sincere bidding (i.e., bidding the true valuations) is a weakly dominant strategy for everyone. Formally:

Strategy-proofness: For each bidder $i$, each bidder $i$ 's valuation $v_{i}$, each bidder $i$ 's bid $b_{i}$, and each other bidders' bids $b_{-i}$,

$$
\left.U\left(d_{i}\left(v_{i}, b_{-i}\right), m_{i}\left(v_{i}, b_{-i}\right) ; v_{i}\right) \geq U\left(d_{i}\left(b_{i}, b_{-i}\right), m_{i}\left(b_{i}, b_{-i}\right)\right) ; v_{i}\right) .
$$

The following rules are central in the literature on auction theory.

\footnotetext{
${ }^{10}$ In standard auctions such as the Vickrey auction, the pay-your-bid auction, introduced later, $m_{i}=0$ if $k=0$.
} 
- Vickrey auction: Each bidder $i$ simultaneously submits his/her bid $b_{i}=\left(b_{i}^{1}, b_{i}^{2}\right)$. After the seller collects all bidders' bids, the seller ranks them from the highest to the lowest bid and allocates the two units to the two highest bids. If bidder $i$ wins one (respectively, two) unit, then the bidder has to pay the highest bids (respectively, the sum of the highest and the second-highest bids) from among the other bidders' losing bids.

- Pay-your-bid auction: Each bidder $i$ simultaneously submits hies/her bid $b_{i}=\left(b_{i}^{1}, b_{i}^{2}\right)$. After the seller collects all bidders' bids, the seller ranks them from the highest to the lowest bid and allocates the two units to the two highest bids. If bidder $i$ wins one (respectively, two) unit, then the bidder has to pay $b_{i}^{1}$ (respectively, $\left.b_{i}^{1}+b_{i}^{2}\right)$.

The most important feature of the Vickrey auction is that it is strategy-proof. However, many previous experimental studies report that bidders tend to overbid in Vickrey auctions. The pay-your-bid auction is widely used in real life, while the Vickrey auction is not so. However, in contrast to the Vickrey auction, the pay-your-bid auction is not strategy-proof.

\subsection{Experimental procedures}

We conducted an experiment to test the effect of advice for the Vickrey auction. We used between-subjects design. To distinguish between whether subjects follow the advice because they understand it or obey the advice without understanding it, we also conducted corresponding experiments for the pay-your-bid auction. We have four types of treatments in total:

- Treatment VA: the Vickrey auction with advice

- Treatment VN: the Vickrey auction without advice

- Treatment PA: the pay-your-bid auction with advice

- Treatment PN: the pay-your-bid auction without advice

In each treatment, three bidders compete for two units of identical objects. For each bidder, two integer valuations are drawn from the uniform distribution with the interval 0 to 1000 with increments of 10 . Then, the larger (respectively, smaller) integer is assigned the valuation for the first (respectively, second) unit. All valuations are displayed in Japanese yen (JPY).

VA, PA, and PN each had three experimental sessions, whereas VN had two sessions. We conducted these 11 sessions at Osaka University in March 2015 and July 2016. We recruited student subjects from Osaka University through campus-wide advertisements. None of the students was experienced in this particular type of experiment. No subject attended more than one session. Our experiment was computerized using the experimental software z-Tree (Fischbacher 2007). Twenty-one or twenty-four subjects participated in each session. Table 1 summarizes the number of observations. Figure 1 illustrates the timeline of one session. 
Each subject was seated at a computer terminal assigned by a lottery. All terminals were separated by partitions. No communication among subjects was allowed. Each subject had a set of printed instructions and a recording sheet. ${ }^{11}$ The experimenter read aloud the instructions. Then, subjects answered a 17-question quiz that tested whether they understood the auction rule that they had been informed of a short time ago. Every correct answer was worth $\$ 0.3(\$ 1=$ JPY 100). The experimenter read aloud the answers to the quiz. Subsequently, only in VA and PA, the experimenter distributed a paper with written advice and also read it aloud. The text of the advice is as below:

"The following advice is about the auction in which you are participating. Please consider carefully whether this advice is true or false. It is completely up to you whether you follow the advice or not.

You can maximize your earnings by bidding your valuations as they are, regardless of what others bid."

Note that the advice involves no deception problem for VA and PA. The subjects were given time to ask questions before proceeding to two practice periods and to the 25 successive payment periods under the random matching protocol. At the beginning of each period, all subjects were separated into groups of three. At the bidding stage, each subject was asked to enter his/her two bids as nonnegative integers - such that the first unit bid is weakly greater than that of the second unit bidinto a box on the display screen. We set the maximum feasible first unit bid to 2000 .

After the 25 payment periods, the subjects completed a questionnaire and were immediately paid in cash. Each subject was privately paid the sum of his/her earnings over the 25 periods. Individual payments including (or excluding) participation fees and quiz points ranged from $\$ 19.1$ to $\$ 85.4$ (or from $\$ 5.9$ to $\$ 70.3$ ).

\subsection{Hypotheses}

We examine whether the following three factors affect sincere bidding behavior: auction rule, advice, and unit. Thereafter, we apply a normal approximation, unless noted otherwise. ${ }^{12}$

Although it is well known in the literature that the Vickrey auction is strategyproof, several experimental results demonstrate that this fact is non-trivial for an average person. Thus, we predict that the subjects may become aware of the benefit of truth-telling if we provide advice on the strategy-proofness of the Vickrey auction to the subjects. To examine whether this conjecture is true, we formulate the following null hypothesis:

Hypothesis 1 (Advice effect in the Vickrey auction) Providing advice does not increase the rate of sincere bidding in the Vickrey auction.

\footnotetext{
11 The full set of experimental instructions (including screen shots, the quiz, and the questionnaire) is provided in Online Appendix F-L.

12 See Online Appendix A for the detail of statistics.
} 
Table 1 Summary of treatments

\begin{tabular}{llllll}
\hline Treatment & Auction rule & Advice & Date & \# of Sessions & $\begin{array}{l}\text { \# of } \\
\text { Subjects } \\
\text { (Groups) }\end{array}$ \\
\hline VA & Vickrey & Yes & Mar-15 & 3 & $63(21)$ \\
VN & Vickrey & No & Mar-15 & 2 & $48(16)$ \\
PA & Pay-your-bid & Yes & Jul-16 & 3 & $69(23)$ \\
PN & Pay-your-bid & No & Jul-16 & 3 & $72(24)$ \\
\hline
\end{tabular}

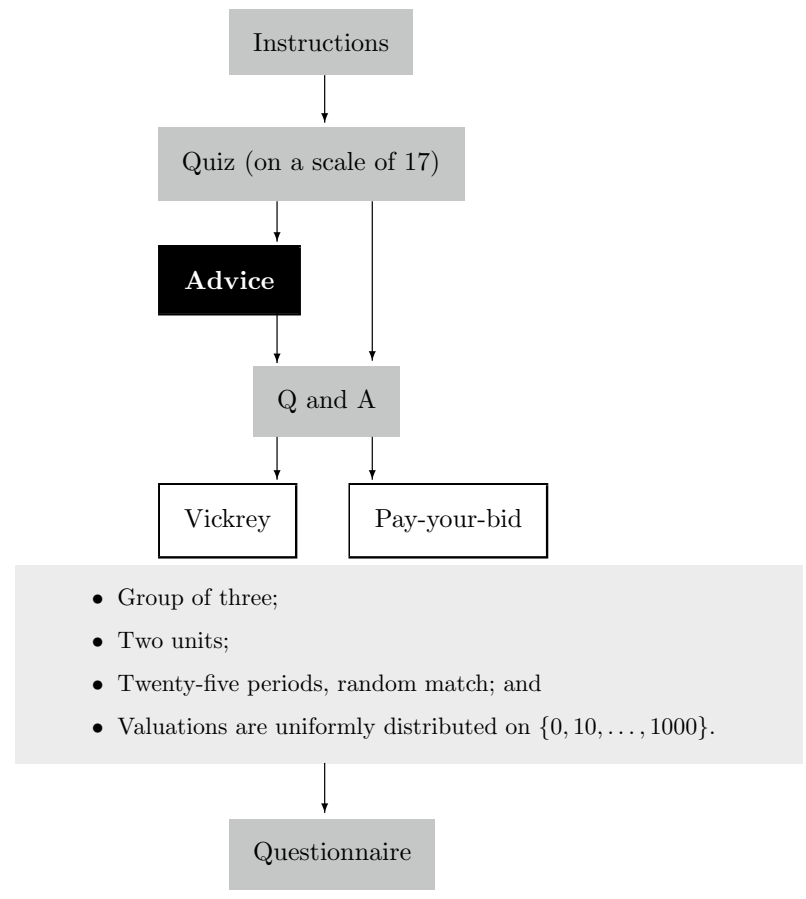

Fig. 1 Timeline of one session

Even if we confirm that the advice effect exists in the Vickrey auction, it is very probable that its effect involves the so-called experimenter demand effect (Zizzo 2009). An excess of effect over the experimenter demand effect is considered a "net effect" of the advice to promote sincere bidding in the Vickrey auction. We call this effect the net advice effect.

As the advice provided in both the Vickrey auction and the pay-your-bid auction is identical, the experimenter demand effects would be similar in both auctions. Moreover, as the advice is false in the pay-your-bid auction, the advice effect is an all experimenter demand effect. Thus, we assume that the net advice effect in the Vickrey auction can be measured by the difference in the advice 
effects in the two auctions. To detect the net advice effect in the Vickrey auction under this assumption, we formulate the following null hypotheses:

Hypothesis 2 (Advice effect in the pay-your-bid auction) Providing advice does not increase the rate of sincere bidding in the pay-your-bid auction.

Hypothesis 3 (Net advice effect in the Vickrey auction) The net advice effect on sincere bidding does not exist in the Vickrey auction.

Subjects who fully understand the procedure of the Vickrey auction are expected to quickly recognize the strategy-proofness of the Vickrey auction based on the advice, even if they are not initially aware. The subjects with perfect scores could be considered those who understand the procedure of the Vickrey auction well, whereas the subjects with imperfect scores could be considered those who do not. Considering this case, we predict that subjects with perfect scores would be more likely to follow the advice than those with imperfect scores. To test this prediction, we formulate the following null hypothesis:

Hypothesis 4 (Relationship between quiz scores and advice effects) The advice effect on sincere bidding does not depend on the pre-play understanding of the Vickrey auction.

As mentioned in the introduction, several experimental studies have observed overbidding in the Vickrey auction. This could cause a severe loss of efficiency. Therefore, we assume that, in the Vickrey auction, providing advice would improve efficiency by reducing such overbidding behavior. To examine whether this assumption is true, we formulate the following null hypothesis:

Hypothesis 5 (Advice effect on efficiency in the Vickrey auction) Providing advice does not improve efficiency within the Vickrey auction.

As in Hypothesis 3, we consider that the net advice effect on efficiency in the Vickrey auction can be measured by the difference in the advice effects on efficiency across the two auctions. To test whether such a net advice effect on efficiency exists in the Vickrey auction, we formulate the following null hypothesis:

Hypothesis 6 (Net advice effect on efficiency in the Vickrey auction) The net advice effect on efficiency does not exist in the Vickrey auction. 


\section{Experimental results}

\subsection{Level of understanding of the auction rules}

Figure 2 displays the distributions of quiz scores. The scores range from 0 to 17. A first look at Fig. 2 clearly shows that over $60 \%$ of the subjects received a perfect score in the Vickrey auction, while over $80 \%$ did so in the pay-your-bid auction. For each auction rule, we find no statistical difference in the score distributions with and without advice. ${ }^{13}$ Similarly, we find no statistical evidence to support the different levels of understanding between the two auctions, regardless of the presence of advice. ${ }^{14}$ In summary, we obtain the following result.

Result 1 (Level of understanding of the auction rules) The majority of subjects had a thorough understanding of the auction rule prior to playing, regardless of whether they participated in the Vickrey or the pay-your-bid auction.

\subsection{Bidding behavior}

For a given unit, we say that a bid is sincere if it matches exactly the valuation drawn for the unit. Similarly, we say that a bid is over (or under) if the bid is more (or less) than the valuation. For example, if valuations and bids are $v_{1}=(800,300)$, $v_{2}=(600,400), v_{3}=(900,500), b_{1}=(850,240), b_{2}=(600,400)$, and $b_{3}=(900,0)$, then the sincere bids are the first and second units of bidder 2 and the first unit of bidder 3, respectively. The unique overbid is bidder 1's first unit, while the remaining two bids are underbids. Hence, the overall average sincere bid rate is 0.5 (i.e., we divide the number of sincere bids by the total number of bids by the three bidders), whereas the average sincere bid rate of bidders 1,2 , and 3 is 0,1 , and 0.5 , respectively.

Figure 3 shows the scatter plots for valuations and bids in each treatment. Initially, the graphs for the Vickrey treatments suggest that, for unit 1, bidders with higher valuations are more likely to overbid. When valuations are close to the maximum, 1000, bids jump as high as 2000. For unit 2, bidding behavior is polarized with an increase in underbidding: overbidding is prevalent regardless of the realized valuations. Further, we observe a cluster of zero biddings when the valuation for unit 2 is no more than 500. Table 2 summarizes the classification of bids into three categories by treatments and periods. ${ }^{15}$

As presented in Panel (a) of Table 2 (VA-VN column), sincere bidding increases by $26.3 \%$ with the statement of strategy-proofness in the Vickrey

\footnotetext{
13 A two-sample Kolmogorov-Smirnov (K-S) test for the equality of two score distributions has a $p$-value $>0.90$ for both VA vs. VN and PA vs. PN. The same conclusions also hold under a chi-square test.

14 The K-S test has a $p$-value $>0.10$ for all pairwise comparisons of (i) VA vs. PA, (ii) VA vs. PN, (iii) VN vs. PA, and (iv) VN vs. PN.

15 See Online Appendix $\mathrm{S}$ for the individual bidding data.
} 


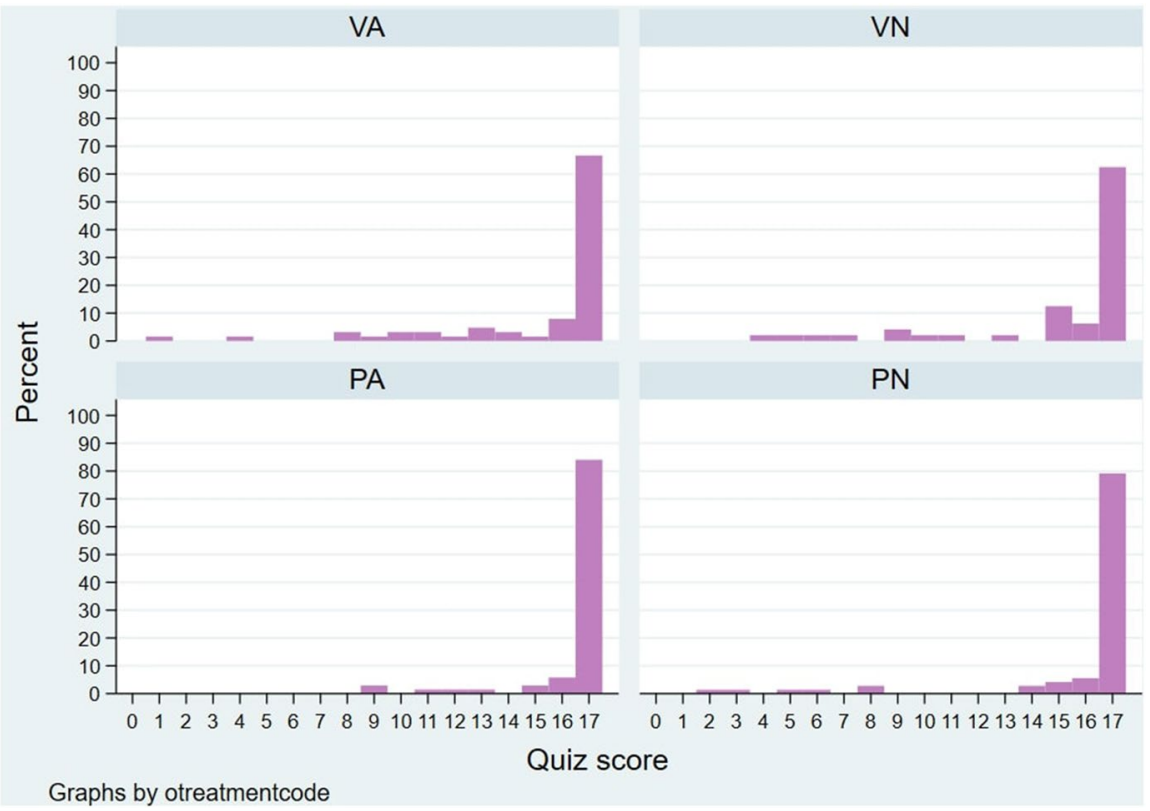

Fig. 2 Distribution of quiz scores

auction. In particular, we observe, from Panels (b) and (c) of Table 2, that the rate of sincere bidding increases further in the former 13 periods than in the latter 12 periods. Specifically, the rate of sincere bidding increases by $28.2 \%$ in the former 13 periods, while the rate increases by $24.3 \%$ in the latter 12 periods. Notice that overbidding is prevalent in the Vickrey auction without advice (VN), which amounts to $63.4 \%$ of all bids. This observation is consistent with findings in the experiments of the multi-unit Vickrey auction by Manelli et al. (2006), Engelmann and Grimm (2009), and Kagel and Levin (2009).

With an explicit statement on the strategy-proofness of the Vickrey auction (VA), $45.3 \%$ of the case is overbidding; this implies that our advice decreases overbidding by $18.1 \%$. Moreover, we find that underbidding also decreases when advice is given to the subjects. Specifically, our advice decreases underbidding by $8.3 \%$. To compare the effect of the advice on overbids and underbids, we calculate the ratio of the reduction rate of overbidding to the rate of overbidding in $\mathrm{VN}$, as well as the ratio of the reduction rate of underbidding to the rate of underbidding in VN. Thus, we find that the advice has more effect on underbids (8.26/16.04) than overbids (18.07/63.38). Even when we break down the data into the former 13 periods and the latter 12 periods, (Panels (b) and (c) of Table 2), the same tendency holds. Conversely, approximately $90 \%$ of the subjects in PA 


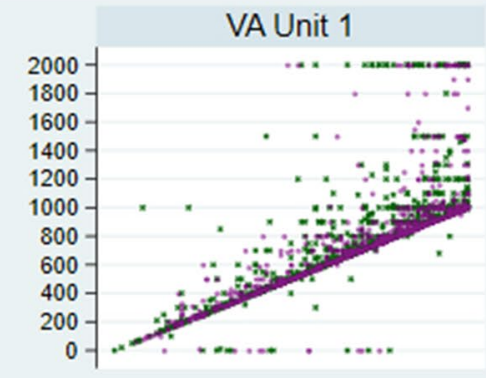

PA Unit 1

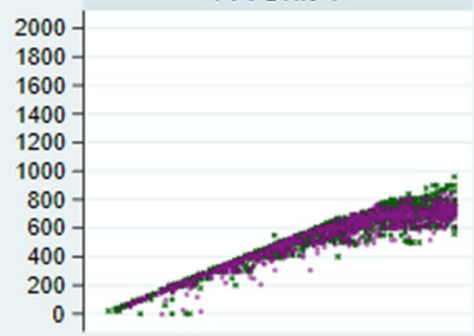

믐

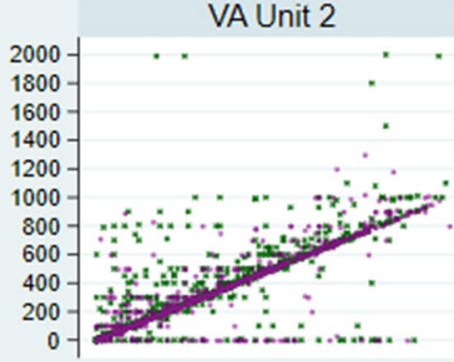

PA Unit 2

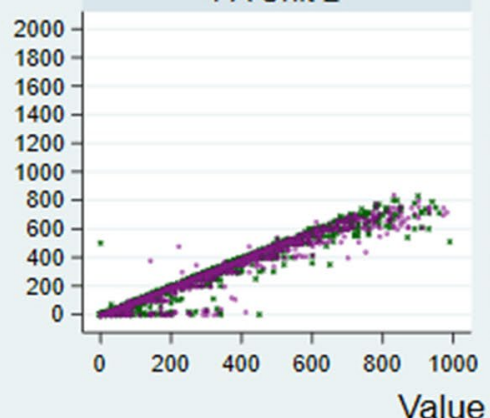

\section{* Periods 1-13 · Periods 14-25}

Graphs by unit and otreatmentcode

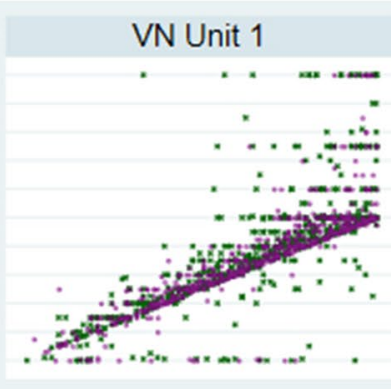

PN Unit 1

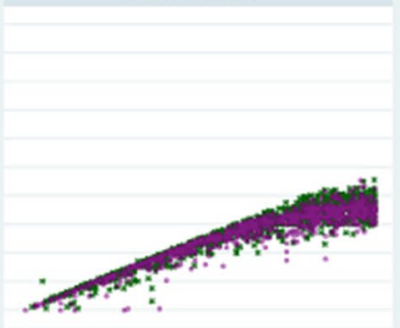

VN Unit 2

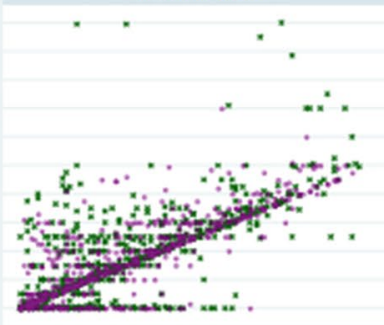

PN Unit 2

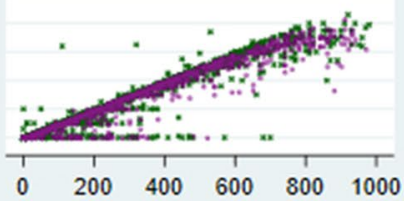

Fig. 3 Scatter plots of bids. Green $\times$ and purple $\bullet$ indicate the bids for the former 13 periods and latter 12 periods, respectively 
Table 2 Bid category by treatments and periods

\begin{tabular}{|c|c|c|c|c|c|c|}
\hline \multirow[t]{2}{*}{ Bid category } & \multicolumn{2}{|l|}{ Vickrey } & \multirow[t]{2}{*}{$V A-V N$} & \multicolumn{2}{|c|}{ Pay-your-bid } & \multirow[t]{2}{*}{$P A-P N$} \\
\hline & VA & VN & & PA & PN & \\
\hline \multicolumn{7}{|l|}{ (a) All } \\
\hline Sincere & $\begin{array}{l}0.469 \\
(0.499)\end{array}$ & $\begin{array}{l}0.206 \\
(0.404)\end{array}$ & $0.263^{* * *}$ & $\begin{array}{l}0.083 \\
(0.276)\end{array}$ & $\begin{array}{l}0.058 \\
(0.234)\end{array}$ & $0.025^{* * *}$ \\
\hline Over & $\begin{array}{l}0.453 \\
(0.498)\end{array}$ & $\begin{array}{l}0.634 \\
(0.482)\end{array}$ & $-0.181^{* * *}$ & $\begin{array}{l}0.006 \\
(0.074)\end{array}$ & $\begin{array}{l}0.009 \\
(0.095)\end{array}$ & $-0.004^{* *}$ \\
\hline Under & $\begin{array}{l}0.078 \\
(0.268)\end{array}$ & $\begin{array}{l}0.160 \\
(0.367)\end{array}$ & $-0.083^{* * *}$ & $\begin{array}{l}0.911 \\
(0.284)\end{array}$ & $\begin{array}{l}0.933 \\
(0.250)\end{array}$ & $-0.021^{* * *}$ \\
\hline \multicolumn{7}{|c|}{ (b) Former 13 periods } \\
\hline Sincere & $\begin{array}{l}0.467 \\
(0.499)\end{array}$ & $\begin{array}{l}0.185 \\
(0.389)\end{array}$ & $0.282^{* * *}$ & $\begin{array}{l}0.093 \\
(0.290)\end{array}$ & $\begin{array}{l}0.058 \\
(0.234)\end{array}$ & $0.034^{* * *}$ \\
\hline Over & $\begin{array}{l}0.453 \\
(0.498)\end{array}$ & $\begin{array}{l}0.629 \\
(0.483)\end{array}$ & $-0.176^{* * *}$ & $\begin{array}{l}0.004 \\
(0.067)\end{array}$ & $\begin{array}{l}0.015 \\
(0.121)\end{array}$ & $-0.010^{* * *}$ \\
\hline Under & $\begin{array}{l}0.080 \\
(0.271)\end{array}$ & $\begin{array}{l}0.186 \\
(0.389)\end{array}$ & $-0.106^{* * *}$ & $\begin{array}{l}0.903 \\
(0.296)\end{array}$ & $\begin{array}{l}0.927 \\
(0.261)\end{array}$ & $-0.024^{* * *}$ \\
\hline \multicolumn{7}{|c|}{ (c) Latter 12 periods } \\
\hline Sincere & $\begin{array}{l}0.472 \\
(0.499)\end{array}$ & $\begin{array}{l}0.228 \\
(0.420)\end{array}$ & $0.243^{* * *}$ & $\begin{array}{l}0.073 \\
(0.260)\end{array}$ & $\begin{array}{l}0.058 \\
(0.234)\end{array}$ & $0.015^{* *}$ \\
\hline Over & $\begin{array}{l}0.453 \\
(0.498)\end{array}$ & $\begin{array}{l}0.639 \\
(0.481)\end{array}$ & $-0.186^{* * *}$ & $\begin{array}{l}0.007 \\
(0.081)\end{array}$ & $\begin{array}{l}0.003 \\
(0.054)\end{array}$ & $0.004^{*}$ \\
\hline Under & $\begin{array}{l}0.075 \\
(0.264)\end{array}$ & $\begin{array}{l}0.133 \\
(0.340)\end{array}$ & $-0.057^{* * *}$ & $\begin{array}{l}0.920 \\
(0.271)\end{array}$ & $\begin{array}{l}0.939 \\
(0.239)\end{array}$ & $-0.019^{* *}$ \\
\hline
\end{tabular}

a) ${ }^{*}$ denotes significant at the $10 \%$ level, ${ }^{* *}$ at the $5 \%$ level, and ${ }^{* * *}$ at the $1 \%$ level. b) Numbers in parentheses are standard deviations

and $\mathrm{PN}$ are likely to underbid. We also observe a 3\%-increase of sincere bidding although the advice is not true in this case. ${ }^{16}$

\subsection{Advice effect}

Table 3 summarizes the frequencies of sincere bidding by treatments, whether the quiz score is perfect, and by units. Table 4 summarizes the frequency of sincere bidding in the former period (periods 1-13) and in the latter period (periods 14-25). ${ }^{17}$

\footnotetext{
16 A simple regression of all bids to valuations strongly shows that the coefficients are 0.8032 for PA and 0.7927 for PN (for the multi-unit pay-your-bid auction, see Lebrun and Tremblay (2003)).

17 We will examine whether the subject's bidding behavior changes over time in Sect. 3.4.
} 
Table 3 Frequency of sincere bidding by treatments, quiz scores, and units

\begin{tabular}{|c|c|c|c|c|c|c|c|}
\hline \multirow[t]{2}{*}{ Data } & \multicolumn{2}{|l|}{ Vickrey } & \multirow{2}{*}{$\begin{array}{l}\text { (1) } \\
V A-V N\end{array}$} & \multicolumn{2}{|c|}{ Pay-your-bid } & \multirow{2}{*}{$\begin{array}{l}(2) \\
P A-P N\end{array}$} & \multirow[t]{2}{*}{$(1)-(2)$} \\
\hline & VA & VN & & PA & PN & & \\
\hline \multicolumn{8}{|l|}{ (a) Both units } \\
\hline All & $\begin{array}{l}0.469 \\
(0.499)\end{array}$ & $\begin{array}{l}0.206 \\
(0.404)\end{array}$ & $0.263^{* * *}$ & $\begin{array}{l}0.083 \\
(0.276)\end{array}$ & $\begin{array}{l}0.058 \\
(0.234)\end{array}$ & $0.025^{* * *}$ & $0.238^{* * *}$ \\
\hline Perfect Score & $\begin{array}{l}0.523 \\
(0.500)\end{array}$ & $\begin{array}{l}0.211 \\
(0.408)\end{array}$ & $0.313^{* * *}$ & $\begin{array}{l}0.079 \\
(0.270)\end{array}$ & $\begin{array}{l}0.046 \\
(0.209)\end{array}$ & $0.034^{* * *}$ & $0.279^{* * *}$ \\
\hline Imperfect Score & $\begin{array}{l}0.361 \\
(0.481)\end{array}$ & $\begin{array}{l}0.198 \\
(0.399)\end{array}$ & $0.163^{* * *}$ & $\begin{array}{l}0.104 \\
(0.305)\end{array}$ & $\begin{array}{l}0.105 \\
(0.307)\end{array}$ & -0.002 & $0.165^{* * *}$ \\
\hline \multicolumn{8}{|l|}{ (b) Unit 1} \\
\hline All & $\begin{array}{l}0.416 \\
(0.493)\end{array}$ & $\begin{array}{l}0.175 \\
(0.380)\end{array}$ & $0.241^{* * *}$ & $\begin{array}{l}0.020 \\
(0.141)\end{array}$ & $\begin{array}{l}0.006 \\
(0.078)\end{array}$ & $0.014^{* * *}$ & $0.227^{* * *}$ \\
\hline Perfect Score & $\begin{array}{l}0.463 \\
(0.499)\end{array}$ & $\begin{array}{l}0.176 \\
(0.381)\end{array}$ & $0.287^{* * *}$ & $\begin{array}{l}0.018 \\
(0.133)\end{array}$ & $\begin{array}{l}0.004 \\
(0.065)\end{array}$ & $0.014^{* * * *}$ & $0.273^{* * *}$ \\
\hline Imperfect Score & $\begin{array}{l}0.322 \\
(0.468)\end{array}$ & $\begin{array}{l}0.173 \\
(0.379)\end{array}$ & $0.149^{* * *}$ & $\begin{array}{l}0.033 \\
(0.178)\end{array}$ & $\begin{array}{l}0.013 \\
(0.115)\end{array}$ & $0.019^{*}$ & $0.129^{* * *}$ \\
\hline \multicolumn{8}{|l|}{ (c) Unit 2} \\
\hline All & $\begin{array}{l}0.523 \\
(0.500)\end{array}$ & $\begin{array}{l}0.237 \\
(0.425)\end{array}$ & $0.286^{* * *}$ & $\begin{array}{l}0.146 \\
(0.353)\end{array}$ & $\begin{array}{l}0.110 \\
(0.313)\end{array}$ & $0.036^{* * *}$ & $0.250^{* * *}$ \\
\hline Perfect Score & $\begin{array}{l}0.584 \\
(0.493)\end{array}$ & $\begin{array}{l}0.245 \\
(0.431)\end{array}$ & $0.338^{* * *}$ & $\begin{array}{l}0.141 \\
(0.348)\end{array}$ & $\begin{array}{l}0.087 \\
(0.282)\end{array}$ & $0.054^{* * *}$ & $0.285^{* * *}$ \\
\hline Imperfect Score & $\begin{array}{l}0.400 \\
(0.490)\end{array}$ & $\begin{array}{l}0.222 \\
(0.416)\end{array}$ & $0.178^{* * *}$ & $\begin{array}{l}0.175 \\
(0.380)\end{array}$ & $\begin{array}{l}0.197 \\
(0.399)\end{array}$ & -0.023 & $0.201^{* * *}$ \\
\hline
\end{tabular}

a) ${ }^{*}$ denotes significant at the $10 \%$ level, ${ }^{* *}$ at the $5 \%$ level, and ${ }^{* * *}$ at the $1 \%$ level. b) Numbers in parentheses are standard deviations

Using mainly both units' data shown in Panel (a) of Table 3, we first test whether the advice increases sincere bidding in each auction rule. We summarize our findings as follows:

\section{Result 2 (Advice effect)}

(i) Providing advice increases the rate of sincere bidding in each auction rule when using all data. The mean increases are $26.3 \%$ (95\% confidence interval, $24.0 \%$ to $28.7 \%$ ) and $2.5 \%$ (95\% confidence interval, $1.3 \%$ to $3.7 \%)$ in the Vickrey auction and in the pay-your-bid auction, respectively.

(ii) The advice is effective in the Vickrey auction even when focusing on the data of the subjects with perfect quiz scores only or of those with imperfect quiz scores only.

(iii) The same advice is effective in the pay-your-bid auction for the subjects with perfect quiz scores rather than those with imperfect quiz scores. 
Table 4 Frequency of sincere bidding by treatments, quiz scores, and periods

\begin{tabular}{|c|c|c|c|c|c|c|c|}
\hline \multirow[t]{2}{*}{ Data } & \multicolumn{2}{|l|}{ Vickrey } & \multirow{2}{*}{$\begin{array}{l}\text { (1) } \\
\text { VA - VN }\end{array}$} & \multicolumn{2}{|c|}{ Pay-your-bid } & \multirow{2}{*}{$\begin{array}{l}(2) \\
P A-P N\end{array}$} & \multirow[t]{2}{*}{$(1)-(2)$} \\
\hline & VA & VN & & PA & PN & & \\
\hline \multicolumn{8}{|c|}{ (a) Former 13 periods } \\
\hline All & $\begin{array}{l}0.467 \\
(0.499)\end{array}$ & $\begin{array}{l}0.185 \\
(0.389)\end{array}$ & $0.282^{* * *}$ & $\begin{array}{l}0.093 \\
(0.290)\end{array}$ & $\begin{array}{l}0.058 \\
(0.234)\end{array}$ & $0.034^{* * *}$ & $0.248^{* * *}$ \\
\hline Perfect Score & $\begin{array}{l}0.511 \\
(0.500)\end{array}$ & $\begin{array}{l}0.182 \\
(0.386)\end{array}$ & $0.329^{* * *}$ & $\begin{array}{l}0.088 \\
(0.284)\end{array}$ & $\begin{array}{l}0.045 \\
(0.208)\end{array}$ & $0.043^{* * *}$ & $0.286^{* * *}$ \\
\hline Imperfect Score & $\begin{array}{l}0.379 \\
(0.486)\end{array}$ & $\begin{array}{l}0.190 \\
(0.393)\end{array}$ & $0.189^{* * *}$ & $\begin{array}{l}0.115 \\
(0.320)\end{array}$ & $\begin{array}{l}0.108 \\
(0.310)\end{array}$ & 0.008 & $0.181^{* * *}$ \\
\hline \multicolumn{8}{|c|}{ (b) Latter 12 periods } \\
\hline All & $\begin{array}{l}0.472 \\
(0.499)\end{array}$ & $\begin{array}{l}0.228 \\
(0.420)\end{array}$ & $0.243^{* * *}$ & $\begin{array}{l}0.073 \\
(0.260)\end{array}$ & $\begin{array}{l}0.058 \\
(0.234)\end{array}$ & $0.015^{* *}$ & $0.228^{* * *}$ \\
\hline Perfect Score & $\begin{array}{l}0.537 \\
(0.499)\end{array}$ & $\begin{array}{l}0.242 \\
(0.428)\end{array}$ & $0.295^{* * *}$ & $\begin{array}{l}0.070 \\
(0.255)\end{array}$ & $\begin{array}{l}0.046 \\
(0.210)\end{array}$ & $0.024^{* * *}$ & $0.271^{* * *}$ \\
\hline Imperfect Score & $\begin{array}{l}0.341 \\
(0.475)\end{array}$ & $\begin{array}{l}0.206 \\
(0.405)\end{array}$ & $0.135^{* * *}$ & $\begin{array}{l}0.091 \\
(0.288)\end{array}$ & $\begin{array}{l}0.103 \\
(0.304)\end{array}$ & -0.012 & $0.147^{* * *}$ \\
\hline
\end{tabular}

a) ${ }^{*}$ denotes significant at the $10 \%$ level, ${ }^{* *}$ at the $5 \%$ level, and ${ }^{* * *}$ at the $1 \%$ level. b) Numbers in parentheses are standard deviations

Support. We first establish (i). Hypothesis 1 is rejected at $p<0.001$. Similarly, Hypothesis 2 is rejected at $p<0.001$. The confidence intervals are calculated using the standard normal distribution. To establish (ii) and (iii), we divide the data into two types: the subjects with perfect scores and those with imperfect scores. Regarding (ii), Hypothesis 1 is rejected at $p<0.001$ in both the data of the subjects with perfect scores and that of those with imperfect scores. We finally establish (iii). Hypothesis 2 is rejected in the data of the subjects with perfect scores $(p<0.001)$, while Hypothesis 2 is not rejected in the data of the subjects with imperfect scores $(p=0.461)$.

The advice effect in the pay-your-bid auction reported in Result 2 should be considered an all experimenter demand effect as the advice is false in that auction. Thus, one might think that the advice effect in the Vickrey auction might also be an experimenter demand effect. However, Result 2 also reports that the advice effect in the Vickrey auction is much larger than that in the pay-your-bid auction. Moreover, the experimenter demand effects would be similar in both auctions because the advice provided in both auctions is identical. These observations suggest that the net advice effect could exist in the Vickrey auction. The following result supports this.

Result 3 (Net advice effect) Providing advice increases the rate of sincere bidding further in the Vickrey auction compared with the pay-your-bid auction, with the mean increase of $23.8 \%$ (95\% confidence interval, $21.2 \%$ to $26.5 \%$ ). 
Support. Hypothesis 3 is rejected at $p<0.001$. The confidence interval is calculated using the standard normal distribution.

The difference, $23.8 \%$, of the advice effects in the two auctions is considered the net advice effect in the Vickrey auction. Many authors investigate why subjects do not bid sincerely in the Vickrey auction by proposing alternative explanations. Result 3 suggests that a considerable amount of such behavior might be mitigated by providing advice that helps understand the strategy-proofness of the Vickrey auction.

We finally test whether quiz scores affect the responsiveness to our advice in the Vickrey auction. The following result demonstrates that the responsiveness to our advice depends on the quiz scores in the Vickrey auction.

Result 4 (Relationship between quiz scores and advice effects) Within the Vickrey auction, the subjects with perfect quiz scores are more responsive to advice than those with imperfect quiz scores. The mean difference between the two groups in terms of an increase in the rate of sincere bidding is $15.0 \%$ (95\% confidence interval, $10.1 \%$ to $20.0 \%$ ).

Support. Hypothesis 4 is rejected at $p<0.001$. The confidence interval is calculated using the standard normal distribution.

Result 4 suggests that under the advice, subjects who properly understand the procedure of the Vickrey auction tend to bid more sincerely than those who do not.

\subsection{Regression analysis of sincere bidding}

We perform a regression analysis to check the robustness of the results, and almost all results are confirmed. We employ a logit model with a random effect at the individual level. The dependent variable is a dummy variable of sincere bidding, which takes the value of 1 if subject $i$ in period $t$ bids sincerely. The three independent variables are the same ones we examined independently above: Advice is a dummy for treatments with advice; Latter is a dummy for periods more than 13; and Perfect Score is a dummy for subjects with a perfect score in the quiz. We also include the interaction terms of these three variables. Table 5 summarizes the results by auction rules and units. For each auction rule and each unit, we run three regressions with different specifications.

The highlights of the logit model regression results are as follows.

- Vickrey: Advice in specifications from (1) to (6) has positive coefficients for both units, supporting Result 2. Meanwhile, Advice $\times$ Perfect Score has an insignificant impact. This is seemingly inconsistent with Result 4, but seems a natural consequence of allowing a random effect, where the impact is regarded as individual characteristics. Moreover, the insignificant effect in Latter and Advice $\times$ Latter in specifications (3) and (6) suggests that the rate of sincere 
bidding does not change over time and the advice quickly improves the rate of sincere bidding in earlier periods. ${ }^{18}$ This quick effect of advice is consistent with Table 4.

- Pay-your-bid: Specification (9) suggests that, with advice, the sincere bidding rate marginally increases over time. Specification (12) with the negative coefficient of Perfect Score confirms that the subjects become less likely to bid sincerely as they understand the auction rule correctly. These are consistent with Tables 2 and 3.

The literature reports mixed results on whether the second price auction subjects learn to bid sincerely from experiencing losses owing to overbidding. For example, Cooper and Fang (2008) observe learning, while Harstad (2000) does not. Using an additional regression, we do not find such evidence in any of the two auction rules, and this is consistent with Harstad (2000).

\subsection{Efficiency, bidders' payoffs, and seller's revenue}

Our efficiency measure is taken from Kagel and Levin (2009). ${ }^{19}$ In one game, if bidder $i$ is the winner with the highest bid and if bidder $j$ is the winner with the secondhighest bid, then the observed efficiency ratio $r$ is given by $\frac{v_{i}^{1}+v_{j}^{1}}{v[1]+v[2]}$ if $i \neq j$ and by $\frac{v_{i}^{1}+v_{i}^{2}}{v[1]+v[2]}$ if $i=j$, where $v[1], v[2]$ denote the two highest units among six valuations $\left(v_{1}^{1}, v_{1}^{2}, v_{2}^{1}, v_{2}^{2}, v_{3}^{1}, v_{3}^{2}\right)$. The efficiency ratio of the full or part of a treatment is the average of the efficiency ratios in the games in the full treatment or part of the treatment.

Table 6 summarizes the results on efficiency with a focus on experience. ${ }^{20}$ In Table 6, the upper (or middle, bottom) panel collects the results obtained for all periods (periods 1-13 and periods 14-25, respectively).

Result 5 (Advice effect on efficiency) Providing advice improves efficiency in the Vickrey auction, particularly in the former 13 periods.

Support. Hypothesis 5 is rejected at the 5\% significance level $(p=0.020)$. To obtain further insights, we divide the data into two types: periods 1-13 and 14-25.

\footnotetext{
18 Together with the insignificant effect in Advice $\times$ Latter $\times$ Perfect Score, this result suggests that the learning process is similar between groups with different levels of understanding of auction rules whenever advice is provided.

19 See also Kwasnica and Sherstyuk (2013).

20 Engelmann and Grimm (2009) compare the Vickrey auction with the pay-your-bid auction by conducting an experiment, where two units of an identical object are auctioned to two bidders with flat demand. Their experimental results are similar to ours in regard to the comparison of the efficiency ratios in the two auctions.
} 
Table 5 Regression analysis of sincere bidding

\begin{tabular}{|c|c|c|c|c|c|c|}
\hline \multicolumn{7}{|l|}{ (a) Vickrey } \\
\hline & \multicolumn{3}{|l|}{ Unit 1} & \multicolumn{3}{|l|}{ Unit 2} \\
\hline & (1) & (2) & (3) & (4) & (5) & (6) \\
\hline Advice & $\begin{array}{l}1.986^{*} \\
(1.103)\end{array}$ & $\begin{array}{l}3.289^{* * * *} \\
(0.709)\end{array}$ & $\begin{array}{l}2.291^{* *} \\
(1.135)\end{array}$ & $\begin{array}{l}1.829^{* *} \\
(0.888)\end{array}$ & $\begin{array}{l}2.466^{* * * *} \\
(0.556)\end{array}$ & $\begin{array}{l}2.044^{* *} \\
(0.916)\end{array}$ \\
\hline Perfect Score & $\begin{array}{l}-0.135 \\
(1.059)\end{array}$ & & $\begin{array}{l}-0.583 \\
(1.100)\end{array}$ & $\begin{array}{l}0.613 \\
(0.831)\end{array}$ & & $\begin{array}{l}0.424 \\
(0.861)\end{array}$ \\
\hline Advice $\times$ Perfect Score & $\begin{array}{l}1.308 \\
(1.375)\end{array}$ & & $\begin{array}{l}1.563 \\
(1.420)\end{array}$ & $\begin{array}{l}0.732 \\
(1.105)\end{array}$ & & $\begin{array}{l}0.592 \\
(1.141)\end{array}$ \\
\hline Latter & & $\begin{array}{l}0.652^{* * *} \\
(0.225)\end{array}$ & $\begin{array}{l}0.187 \\
(0.347)\end{array}$ & & $\begin{array}{l}0.452^{* *} \\
(0.182)\end{array}$ & $\begin{array}{l}0.211 \\
(0.309)\end{array}$ \\
\hline Advice $\times$ Latter & & $\begin{array}{l}-0.802^{* * *} \\
(0.273)\end{array}$ & $\begin{array}{l}-0.622 \\
(0.438)\end{array}$ & & $\begin{array}{l}-0.236 \\
(0.231)\end{array}$ & $\begin{array}{l}-0.433 \\
(0.389)\end{array}$ \\
\hline Latter $\times$ Perfect Score & & & $\begin{array}{l}0.798^{*} \\
(0.459)\end{array}$ & & & $\begin{array}{l}0.363 \\
(0.382)\end{array}$ \\
\hline Advice $\times$ Latter $\times$ Perfect Score & & & $\begin{array}{l}-0.373 \\
(0.564)\end{array}$ & & & $\begin{array}{l}0.337 \\
(0.485)\end{array}$ \\
\hline Constant & $\begin{array}{l}-3.253^{* * *} \\
(0.845)\end{array}$ & $\begin{array}{l}-3.707^{* * *} \\
(0.565)\end{array}$ & $\begin{array}{l}-3.360^{* * *} \\
(0.872)\end{array}$ & $\begin{array}{l}-2.323^{* * *} \\
(0.662)\end{array}$ & $\begin{array}{l}-2.173^{* * *} \\
(0.422)\end{array}$ & $\begin{array}{l}-2.432^{* * *} \\
(0.685)\end{array}$ \\
\hline Observations & 2,775 & 2,775 & 2,775 & 2,775 & 2,775 & 2,775 \\
\hline Akaike Inf. Crit. & $1,909.857$ & $1,902.138$ & $1,903.642$ & $2,193.692$ & $2,189.629$ & $2,187.752$ \\
\hline
\end{tabular}

(b) Pay-your-bid

\begin{tabular}{|c|c|c|c|c|c|c|}
\hline & \multicolumn{3}{|l|}{ Unit 1} & \multicolumn{3}{|l|}{ Unit 2} \\
\hline & (7) & (8) & (9) & $(10)$ & (11) & (12) \\
\hline Advice & $\begin{array}{l}1.177 \\
(1.111)\end{array}$ & $\begin{array}{l}1.100^{*} \\
(0.660)\end{array}$ & $\begin{array}{l}0.215 \\
(1.240)\end{array}$ & $\begin{array}{l}-0.005 \\
(0.664)\end{array}$ & $\begin{array}{l}0.673^{* *} \\
(0.317)\end{array}$ & $\begin{array}{l}0.331 \\
(0.699)\end{array}$ \\
\hline Perfect Score & $\begin{array}{l}-1.091 \\
(0.970)\end{array}$ & & $\begin{array}{l}-1.594 \\
(1.079)\end{array}$ & $\begin{array}{l}-0.936^{*} \\
(0.496)\end{array}$ & & $\begin{array}{l}-0.924^{*} \\
(0.529)\end{array}$ \\
\hline Advice $\times$ Perfect Score & $\begin{array}{l}0.447 \\
(1.290)\end{array}$ & & $\begin{array}{l}1.405 \\
(1.476)\end{array}$ & $\begin{array}{l}0.609 \\
(0.740)\end{array}$ & & $\begin{array}{l}0.469 \\
(0.782)\end{array}$ \\
\hline Latter & & $\begin{array}{l}-0.506 \\
(0.643)\end{array}$ & $\begin{array}{l}-1.443 \\
(1.160)\end{array}$ & & $\begin{array}{l}0.028 \\
(0.172)\end{array}$ & $\begin{array}{l}0.046 \\
(0.308)\end{array}$ \\
\hline Advice $\times$ Latter & & $\begin{array}{l}0.783 \\
(0.735)\end{array}$ & $\begin{array}{l}2.334^{*} \\
(1.381)\end{array}$ & & $\begin{array}{l}-0.499^{* *} \\
(0.234)\end{array}$ & $\begin{array}{l}-0.778 \\
(0.497)\end{array}$ \\
\hline Latter $\times$ Perfect Score & & & $\begin{array}{l}1.541 \\
(1.425)\end{array}$ & & & $\begin{array}{l}-0.025 \\
(0.371)\end{array}$ \\
\hline Advice $\times$ Latter $\times$ Perfect Score & & & $\begin{array}{l}-2.343 \\
(1.660)\end{array}$ & & & $\begin{array}{l}0.341 \\
(0.566)\end{array}$ \\
\hline Constant & $\begin{array}{l}-5.841^{* * *} \\
(0.949)\end{array}$ & $\begin{array}{l}-6.549^{* * *} \\
(0.761)\end{array}$ & $\begin{array}{l}-5.379^{* * *} \\
(0.974)\end{array}$ & $\begin{array}{l}-2.144^{\text {**** }} \\
(0.439)\end{array}$ & $\begin{array}{l}-2.901^{\text {**** }} \\
(0.237)\end{array}$ & $\begin{array}{l}-2.169^{* * *} \\
(0.465)\end{array}$ \\
\hline Observations & 3,525 & 3,525 & 3,525 & 3,525 & 3,525 & 3,525 \\
\hline Akaike Inf. Crit. & 445.609 & 446.079 & 450.302 & $2,231.654$ & $2,226.571$ & $2,230.219$ \\
\hline
\end{tabular}


Table 5 (continued)

a) ${ }^{*}$ denotes significant at the $10 \%$ level, ${ }^{* *}$ at the $5 \%$ level, and ${ }^{* * *}$ at the $1 \%$ level. b) Numbers in parentheses are standard errors

Table 6 Efficiency by treatments and periods

\begin{tabular}{|c|c|c|c|c|c|c|c|}
\hline \multirow[t]{2}{*}{ Data } & \multicolumn{2}{|l|}{ Vickrey } & \multirow{2}{*}{$\begin{array}{l}\text { (1) } \\
\text { VA - VN }\end{array}$} & \multicolumn{2}{|c|}{ Pay-your-bid } & \multirow{2}{*}{$\begin{array}{l}\text { (2) } \\
P A-P N\end{array}$} & \multirow[t]{2}{*}{$(1)-(2)$} \\
\hline & VA & VN & & PA & PN & & \\
\hline All periods & $\begin{array}{l}0.977 \\
(0.069)\end{array}$ & $\begin{array}{l}0.967 \\
(0.081)\end{array}$ & $0.010^{* *}$ & $\begin{array}{l}0.990 \\
(0.028)\end{array}$ & $\begin{array}{l}0.988 \\
(0.029)\end{array}$ & 0.002 & $0.009^{*}$ \\
\hline Periods 1-13 & $\begin{array}{l}0.970 \\
(0.080)\end{array}$ & $\begin{array}{l}0.956 \\
(0.098)\end{array}$ & $0.015^{* *}$ & $\begin{array}{l}0.991 \\
(0.026)\end{array}$ & $\begin{array}{l}0.989 \\
(0.029)\end{array}$ & 0.002 & $0.012^{*}$ \\
\hline Periods $14-25$ & $\begin{array}{l}0.984 \\
(0.053)\end{array}$ & $\begin{array}{l}0.978 \\
(0.054)\end{array}$ & 0.006 & $\begin{array}{l}0.989 \\
(0.030)\end{array}$ & $\begin{array}{l}0.988 \\
(0.028)\end{array}$ & 0.001 & 0.004 \\
\hline
\end{tabular}

a) ${ }^{*}$ denotes significant at the $10 \%$ level, ${ }^{* *}$ at the $5 \%$ level, and ${ }^{* * *}$ at the $1 \%$ level. b) Numbers in parentheses are standard deviations

Then, Hypothesis 5 is rejected at the 5\% significance level in the data of periods $1-13(p=0.039)$, while Hypothesis 5 is not rejected in the data of periods $14-25$ $(p=0.143)$.

Result 5 suggests that improvements in the efficiency of the Vickrey auction occur mainly when the subjects are less experienced.

Result 6 (Net advice effect on efficiency) The net advice effect on efficiency exists in the Vickrey auction, particularly in the former 13 periods.

Support. Hypothesis 6 is rejected at the $10 \%$ significance level $(p=0.051)$. Again, we divide the data into two: periods 1-13 and 14-25. Then, Hypothesis 6 is rejected at the $10 \%$ significance level in the data of periods $1-13(p=0.074)$, while Hypothesis 6 is not rejected in the data of periods $14-25(p=0.218)$.

Result 6 suggests that a relative improvement in the efficiency of the Vickrey auction compared with the pay-your-bid auction occurs mainly when the subjects are less experienced. ${ }^{21}$

\footnotetext{
${ }^{21}$ We also test the same hypotheses using an alternative way of defining efficiency, which we call the "binary efficiency." In this efficiency measure, we focus only on whether an efficient allocation is realized in a group observation. Then, Result 5 holds even if we use the binary efficiency as a measure of efficiency (see Online Appendix B for more details).
} 
Table 7 Average bidder's payoff and average seller's revenue per auction

\begin{tabular}{|c|c|c|c|c|c|c|}
\hline & \multicolumn{2}{|l|}{ Vickrey } & \multirow[t]{2}{*}{$\mathrm{VA}-\mathrm{VN}$} & \multicolumn{2}{|c|}{ Pay-your-bid } & \multirow[t]{2}{*}{$P A-P N$} \\
\hline & VA & VN & & PA & PN & \\
\hline \multicolumn{7}{|c|}{ (a) Bidder's payoff } \\
\hline All periods & $\begin{array}{l}136.844 \\
(225.109)\end{array}$ & $\begin{array}{l}122.292 \\
(221.572)\end{array}$ & $14.553^{* *}$ & $\begin{array}{l}82.829 \\
(105.467)\end{array}$ & $\begin{array}{l}89.928 \\
(111.454)\end{array}$ & $-7.099^{* *}$ \\
\hline Periods $1-13$ & $\begin{array}{l}132.247 \\
(235.584)\end{array}$ & $\begin{array}{l}115.000 \\
(231.757)\end{array}$ & $17.247^{*}$ & $\begin{array}{l}78.997 \\
(101.469)\end{array}$ & $\begin{array}{l}83.301 \\
(107.679)\end{array}$ & -4.305 \\
\hline Periods 14-25 & $\begin{array}{l}141.825 \\
(213.225)\end{array}$ & $\begin{array}{l}130.191 \\
(209.896)\end{array}$ & 11.634 & $\begin{array}{l}86.981 \\
(109.545)\end{array}$ & $\begin{array}{l}97.106 \\
(115.037)\end{array}$ & $-10.126^{* *}$ \\
\hline \multicolumn{7}{|c|}{ (b) Seller's revenue } \\
\hline All periods & $\begin{array}{l}1139.410 \\
(397.611)\end{array}$ & $\begin{array}{l}1125.875 \\
(431.408)\end{array}$ & 13.535 & $\begin{array}{l}1303.704 \\
(180.917)\end{array}$ & $\begin{array}{l}1288.700 \\
(196.875)\end{array}$ & $15.004^{*}$ \\
\hline Periods $1-13$ & $\begin{array}{l}1144.689 \\
(406.210)\end{array}$ & $\begin{array}{l}1142.933 \\
(428.434)\end{array}$ & 1.756 & $\begin{array}{l}1313.211 \\
(190.073)\end{array}$ & $\begin{array}{l}1303.397 \\
(211.432)\end{array}$ & 9.813 \\
\hline Periods 14-25 & $\begin{array}{l}1133.690 \\
(388.806)\end{array}$ & $\begin{array}{l}1107.396 \\
(434.969)\end{array}$ & 26.295 & $\begin{array}{l}1293.406 \\
(170.189)\end{array}$ & $\begin{array}{l}1272.778 \\
(178.786)\end{array}$ & $20.628^{*}$ \\
\hline
\end{tabular}

a) ${ }^{*}$ denotes significant at the $10 \%$ level, ${ }^{* *}$ at the $5 \%$ level, and ${ }^{* * *}$ at the $1 \%$ level. b) Numbers in parentheses are standard deviations

We finally ask whether the advice affects bidders' payoffs and the seller's revenue in each auction rule. Table 7 summarizes the results on the bidders' payoffs and the seller's revenue. We then make the following observations:

Result 7 (Bidders' payoffs and seller's revenue)

(i) The advice marginally increases (or decreases) the bidder's payoff per auction in the Vickrey (or pay-your-bid) auction using all data.

(ii) Providing advice does not affect the seller's revenue in the Vickrey auction, while the advice marginally increases the seller's revenue in the pay-your-bid auction using all data.

The increase in the bidders' payoffs in the Vickrey auction is consistent with the efficiency gain that we reported previously.

\section{Ausubel auction}

We further conducted an experiment to test the effect of advice for the Ausubel auction (Ausubel 2004), which is considered a dynamic version of the Vickrey auction. In the Ausubel auction (Ausubel 2004), rather than reporting their valuations for the objects to the auctioneer, all bidders gradually reveal their demands at given prices 
(or equivalently, their dropout prices), until the auction ends. The Ausubel auction can be described as follows:

- Ausubel auction: In this auction, a price is gradually increased from 0 . At each price $p$, each bidder $i$ reports their demand $D_{i}(p) \in\{0,1,2\}$. Note that, for each bidder $i, D_{i}(0)=2$ and $D_{i}$ are non-increasing in $p$. For each price $p$ and each bidder $i$, let $D(p) \equiv D_{1}(p)+D_{2}(p)+D_{3}(p)$ and $D_{-i}(p) \equiv D(p)-D_{i}(p)$ denote the aggregate demand at $p$ and the aggregate demand of all other bidders except $i$, respectively. As the price $p$ rises, the aggregate demand $D(p)$ will drop, and, at a certain $p^{*}$, there is a bidder, say bidder $i^{*}$, such that $D_{-i^{*}}\left(p^{*}\right)=1$. At this price, the competitors of bidder $i^{*}$ demand one unit less than the available number of units (two units); thus, bidder $i^{*}$ surely obtains one unit. Then, we say that bidder $i^{*}$ has clinched one unit. Bidder $i^{*}$ 's payment for it is the price at which they have clinched it, $p^{*}$. Therefore, both the available number of units and the bidder $i^{*}$ 's demand are reduced by one unit, and the auction continues until the available number of units becomes 0 .

We focus on the Ausubel auction with dropout information, where all dropout prices are publicly revealed as they occur. In this auction rule, bidder $i$ 's sincere bidding, which consists of both reporting two demands until the price equals $v_{i}^{2}$ and reporting one demand until the price equals $v_{i}^{1}$, is not a weakly dominant strategy (Kagel and Levin 2009). ${ }^{22}$ However, it is well known that sincere bidding is an ex-post equilibrium (Ausubel 2004; Okamoto 2018). ${ }^{23}$ Therefore, one can expect that providing advice on this property improves the performance of the Ausubel auction, similar to that of the Vickrey auction.

\subsection{Experimental procedures}

To compare the results of the Ausubel auction with those of the Vickrey auction, the experimental settings for the Ausubel auction are the same as the experimental settings for the Vickrey auction. This follow-up experiment consists of two treatments:

- Treatment AA: the Ausubel auction with advice

- Treatment AN: the Ausubel auction without advice

We conducted three experimental sessions in each of AA and AN at Osaka University in February 2020. A total of 9, 21, or 24 subjects participated in each session. We recruited student subjects from Osaka University through campus-wide

\footnotetext{
22 If dropout information is not publicly announced (i.e., the Ausubel auction without dropout information), sincere bidding is a weakly dominant strategy for everyone (Ausubel 2004; Kagel and Levin 2009). 23 This is equivalent to saying that the Ausubel auction is ex-post incentive compatible. Moreover, in the Ausubel auction, sincere bidding is an ex-post equilibrium even off the equilibrium paths; that is, it is an ex-post perfect equilibrium (Ausubel 2004; Okamoto 2018).
} 
Table 8 Summary of treatments

\begin{tabular}{llllll}
\hline Treatment & Auction rule & Advice & Date & \# of Sessions & $\begin{array}{l}\text { \# of } \\
\text { Subjects } \\
\text { (Groups) }\end{array}$ \\
\hline AA & Ausubel & Yes & Feb-20 & 3 & $54(18)$ \\
AN & Ausubel & No & Feb-20 & 3 & $57(19)$ \\
\hline
\end{tabular}

advertisements. None of the students were experienced in this particular type of experiment, and no subject attended more than one session. Table 8 summarizes the number of observations.

The experimental procedure is exactly the same as that described in Sect. 2.2 except for the content of advice. ${ }^{24}$ Specifically, the text of the advice is as follows:

"The following advice is about the auction in which you are participating. Please consider carefully whether this advice is true or false. It is completely up to you whether you follow the advice or not.

You can maximize your earnings by reducing your demands at your values as they are, regardless of the prices at which others reduce their demands."

Note that the advice involves no deception problem for AA. One period of the Ausubel auction proceeds as follows. The price is gradually increased from 0 to 2000, which is equal to the maximum possible bid in our Vickrey treatments. The price rises in increments of $10 \mathrm{JPY}$ every two seconds. ${ }^{25}$ Each subject clicks a button on the screen to reduce his/her demand by one unit. The auction ends when the aggregate demand becomes two (i.e., the button is clicked four times), unless the price reaches 2000 .

After the 25 payment periods, the subjects completed a questionnaire and were immediately paid in cash. Each subject was privately paid the sum of his/her earnings over the 25 periods. Individual payments including (or excluding) participation fees and quiz points ranged from $\$ 32.6$ to $\$ 91.5$ (or from $\$ 18.1$ to $\$ 76.4$ ).

\subsection{Hypotheses}

Similarly to Sect. 2.3, we apply a normal approximation to examine whether the following three factors affect sincere bidding behavior: auction rule, advice, and unit.

As mentioned previously, sincere bidding is an ex-post equilibrium in the Ausubel auction. Based on this theoretical result, we expect that providing advice could

\footnotetext{
${ }^{24}$ The full set of experimental instructions (including screen shots, quiz, and questionnaire) is provided in Online Appendix M-R.

${ }^{25}$ The price increased by 10 JPY every 3 seconds in the first sessions in each of AA and AN. However, to complete one session within three hours, we subsequently modified the clock speed to 2 seconds from the second session onward.
} 
increase the rate of sincere bidding in the Ausubel auction similar to the Vickrey auction. To examine whether this conjecture is true, we formulate the following null hypothesis:

Hypothesis 1' (Advice effect in the Ausubel auction). Providing advice does not increase the rate of sincere bidding in the Ausubel auction.

If an advice effect exists in the Ausubel auction, then not all of the effect would be the experimenter demand effect because the advice is correct in the Ausubel auction. Thus, the Ausubel auction would have a net advice effect. We are concerned with the difference in the net advice effect between strategy-proof and non-strategyproof mechanisms (i.e., the Vickrey and Ausubel auctions) at this time. Since winners' demand reductions are censored in the Ausubel auction, we focus on non-winning bids in the Vickrey treatments for a fair comparison of these two auction rules. To examine this comparison, we consider the following null hypothesis:

Hypothesis 3' (Relative effect of advice on sincere bidding). When we focus on nonwinning bids, no difference exists in the advice effect on sincere bidding between Ausubel and Vickrey auctions.

Similar to the Vickrey auction, we predict that subjects with perfect scores would be more likely to follow the advice than those with imperfect scores even in the Ausubel auction. We also expect that providing advice would improve efficiency even in the Ausubel auction. To test these predictions, we formulate the following null hypotheses:

Hypothesis 4' (Relationship between quiz scores and advice effects). The advice effect on sincere bidding does not depend on the pre-play understanding of the Ausubel auction.

Hypothesis 5' (Advice effect on efficiency in the Ausubel auction). Providing advice does not improve efficiency within the Ausubel auction.

\subsection{Level of understanding and bidding behavior}

Figure 4 displays the distributions of quiz scores. The scores range from 0 to 17 . In both treatments, almost half of the subjects $(50.0 \%$ and $49.3 \%$ in AA and AN, respectively) had a perfect score in the quiz conducted immediately after instructions had been provided. Then, we obtain the following result:

Result 8 (Level of understanding of the Ausubel auction) In the Ausubel auction, $49.6 \%$ of the subjects had a thorough understanding of the auction rule prior to playing. 


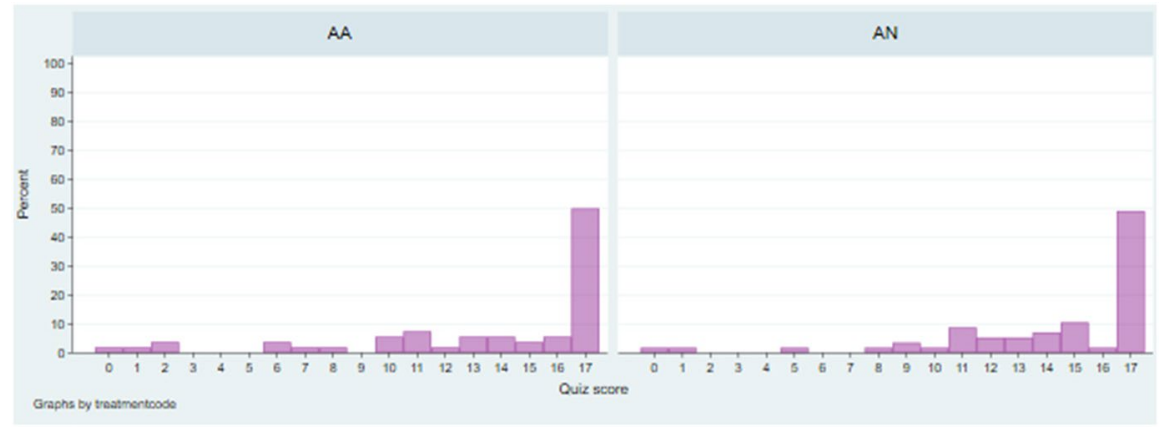

Fig. 4 Distribution of quiz scores for each treatment prior to the auctions

Figure 5 illustrates how bidding behavior contrasts between units in the Ausubel auction. The subjects typically bid sincerely for the first unit, while they overbid for the second unit. This behavior explains $59.0 \%$ and $52.9 \%$, respectively, of the first and second unit bids, when combining the data of the AA and AN. A full categorization of each bid into "Sincere," "Over," and "Under" is summarized in Table 9. Bids are more likely to be sincere over time when the advice is provided. ${ }^{26,27}$

\subsection{Advice effect}

We now examine whether the advice effect exists in the Ausubel auction. We also compare the Ausubel auction with the Vickrey auction. As mentioned previously, this section focuses on non-winning bids in the Vickrey treatments to fairly compare these two auction rules.

Table 10 summarizes the frequencies of sincere bidding by treatments, whether the quiz score is perfect, and by units. Table 11 summarizes the frequency of

\footnotetext{
${ }^{26}$ Interestingly, the dynamic nature of the Ausubel auction induces a unique type of overbidding, which does not prevail in the Vickrey auction treatments: The Ausubel auction subjects tend to reduce demand for the first time when the price reaches the average of two drawn values, $\left(v_{1}+v_{2}\right) / 2$. We now regard the average bidding as the demand reduction within $\$ 0.1$ of the average of the two valuations. It appears that $16.9 \%(=213 / 1263)$ and $11.2 \%(=143 / 1276)$ of the overall first demand reductions in AA and AN, respectively, are caused by such average bidding behavior. A bid observation can simultaneously be interpreted as both the average bid and a sincere one. For example, consider the case where a subject with $\left(v_{1}, v_{2}\right)=(500,490)$ reduced demand to one at a price equal to 490 .

${ }^{27}$ Sincere bidding for the first unit has a justification both from the theoretical and experimental perspectives. Baisa (2020) theoretically shows that two types of bids dominate in the multi-unit Vickrey auction: non-sincere bidding for the first unit and underbidding for the second unit. Moreover, we can regard the situation for the Ausubel subject after his/her first demand reduction as the single-unit English auction. Recall that subjects in English auction experiments have revealed to recognize easily that it is beneficial to remain in the auction up to their own value (Li 2017; McGee and Levin 2019; Breitmoser and Schweighofer-Kodritsch 2021). Accordingly, it is natural that most subjects bid sincerely for the first unit in our Ausubel auction treatments.
} 


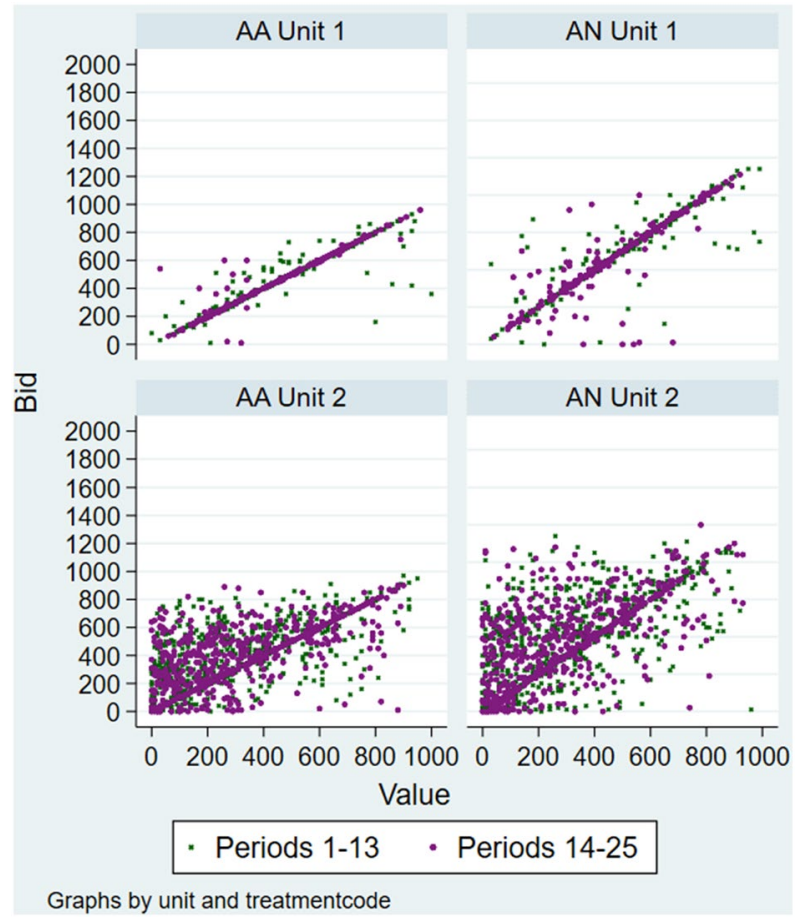

Fig. 5 Scatter plots of bids. Green $\times$ and purple $\bullet$ indicate bids for the former 13 periods and latter 12 periods, respectively

sincere bidding in the former period (periods 1-13) and in the latter period (periods $14-25) .^{28}$

Using mainly both units' data shown in Panel (a) of Table 10, we first test whether the advice increases sincere bidding in the Ausubel auction. We summarize our findings as follows:

\section{Result 9 (Advice effect in the Ausubel auction)}

(i) Providing advice increases the rate of sincere bidding in the Ausubel auction when using all data. The mean increase is $8.4 \%$ (95\% confidence interval, 5.3\% to $11.5 \%$ ).

(ii) The advice is effective even when only focusing on the data of the subjects with perfect quiz scores only or of those with imperfect quiz scores.

Support. We first establish (i). Hypothesis 1 ' is rejected at $p<0.001$. To establish (ii), we divide the data into two types: the subjects with perfect scores and those with imperfect scores. Then, Hypothesis $1^{\prime}$ is rejected in the data of the subjects

\footnotetext{
${ }_{28}$ We will examine whether the subject's bidding behavior changes over time in Online Appendix S.
} 
Table 9 Bid category by treatments and periods in the Ausubel auction

\begin{tabular}{|c|c|c|c|}
\hline Bid category & AA & AN & $A A-A N$ \\
\hline \multicolumn{4}{|l|}{ (a) All } \\
\hline Sincere & $\begin{array}{l}0.389 \\
(0.488)\end{array}$ & $\begin{array}{l}0.305 \\
(0.460)\end{array}$ & $0.084^{* * *}$ \\
\hline Over & $\begin{array}{l}0.415 \\
(0.493)\end{array}$ & $\begin{array}{l}0.427 \\
(0.495)\end{array}$ & -0.012 \\
\hline Under & $\begin{array}{l}0.196 \\
(0.397)\end{array}$ & $\begin{array}{l}0.268 \\
(0.443)\end{array}$ & $-0.072^{* * *}$ \\
\hline \multicolumn{4}{|c|}{ (b) Former 13 periods } \\
\hline Sincere & $\begin{array}{l}0.339 \\
(0.474)\end{array}$ & $\begin{array}{l}0.295 \\
(0.456)\end{array}$ & $0.044^{* *}$ \\
\hline Over & $\begin{array}{l}0.451 \\
(0.498)\end{array}$ & $\begin{array}{l}0.418 \\
(0.493)\end{array}$ & $0.033^{*}$ \\
\hline Under & $\begin{array}{l}0.210 \\
(0.408)\end{array}$ & $\begin{array}{l}0.287 \\
(0.453)\end{array}$ & $-0.077^{* * *}$ \\
\hline \multicolumn{4}{|c|}{ (c) Latter 12 periods } \\
\hline Sincere & $\begin{array}{l}0.443 \\
(0.497)\end{array}$ & $\begin{array}{l}0.317 \\
(0.466)\end{array}$ & $0.126^{* * *}$ \\
\hline Over & $\begin{array}{l}0.376 \\
(0.485)\end{array}$ & $\begin{array}{l}0.437 \\
(0.496)\end{array}$ & $-0.060^{* * *}$ \\
\hline Under & $\begin{array}{l}0.181 \\
(0.385)\end{array}$ & $\begin{array}{l}0.246 \\
(0.431)\end{array}$ & $-0.066^{* * *}$ \\
\hline
\end{tabular}

a) ${ }^{*}$ denotes significant at the $10 \%$ level, ${ }^{* *}$ at the $5 \%$ level, and ${ }^{* * *}$ at the $1 \%$ level. b) Numbers in parentheses are standard deviations

with perfect scores $(p<0.001)$, and it is also rejected in the data of the subjects with imperfect scores $(p<0.05)$.

We observe from Result 9 that the advice effect exists in the Ausubel auction. Thus, we compare our Ausubel auction data with our Vickrey auction data to examine the differences in the advice effects between these two auction rules. Moreover, we compare the two auction rules according to their rates of sincere bidding when advice is provided, given that some experimental studies report that, without advice, the rate of sincere bidding in the Ausubel auction is higher than that in the Vickrey auction (e.g., Kagel and Levin (2009)). We then obtain the following observations from comparing Ausubel and Vickrey auctions.

\section{Result 10 (Comparison of non-winning bids with the Vickrey treatments)}

(i) Without advice, the rate of sincere bidding for non-winning bids is significantly lower in the Vickrey auction than that in the Ausubel auction. Conversely, when advice is provided, the rate of sincere bidding for non-winning bids is significantly higher in the Vickrey auction than that in the Ausubel auction. 
Table 10 Frequency of sincere bidding, by treatments, quiz scores, and units

\begin{tabular}{|c|c|c|c|c|c|c|c|}
\hline \multirow[t]{2}{*}{ Data } & \multicolumn{2}{|l|}{ Ausubel } & \multirow{2}{*}{$\begin{array}{l}(1) \\
A A-A N\end{array}$} & \multicolumn{2}{|l|}{ Vickrey } & \multirow{2}{*}{$\begin{array}{l}\text { (2) } \\
\text { VA - VN }\end{array}$} & \multirow[t]{2}{*}{$(1)-(2)$} \\
\hline & AA & AN & & VA & VN & & \\
\hline \multicolumn{8}{|l|}{ (a) Both units } \\
\hline All & $\begin{array}{l}0.389 \\
(0.488)\end{array}$ & $\begin{array}{l}0.305 \\
(0.460)\end{array}$ & $0.084^{* * *}$ & $\begin{array}{l}0.550 \\
(0.498)\end{array}$ & $\begin{array}{l}0.240 \\
(0.427)\end{array}$ & $0.310^{* * * *}$ & $-0.226^{* * *}$ \\
\hline Perfect Score & $\begin{array}{l}0.427 \\
(0.495)\end{array}$ & $\begin{array}{l}0.295 \\
(0.456)\end{array}$ & $0.132^{* * *}$ & $\begin{array}{l}0.602 \\
(0.490)\end{array}$ & $\begin{array}{l}0.255 \\
(0.436)\end{array}$ & $0.347^{* * *}$ & $-0.215^{* * *}$ \\
\hline Imperfect Score & $\begin{array}{l}0.351 \\
(0.477)\end{array}$ & $\begin{array}{l}0.314 \\
(0.464)\end{array}$ & $0.037^{* *}$ & $\begin{array}{l}0.434 \\
(0.496)\end{array}$ & $\begin{array}{l}0.216 \\
(0.412)\end{array}$ & $0.218^{* * *}$ & $-0.181^{* * *}$ \\
\hline \multicolumn{8}{|l|}{ (b) Unit 1} \\
\hline All & $\begin{array}{l}0.672 \\
(0.470)\end{array}$ & $\begin{array}{l}0.512 \\
(0.500)\end{array}$ & $0.160^{* * *}$ & $\begin{array}{l}0.573 \\
(0.495)\end{array}$ & $\begin{array}{l}0.226 \\
(0.419)\end{array}$ & $0.347^{* * *}$ & $-0.187^{* * *}$ \\
\hline Perfect Score & $\begin{array}{l}0.685 \\
(0.465)\end{array}$ & $\begin{array}{l}0.541 \\
(0.499)\end{array}$ & $0.144^{* * *}$ & $\begin{array}{l}0.616 \\
(0.487)\end{array}$ & $\begin{array}{l}0.252 \\
(0.435)\end{array}$ & $0.365^{* * *}$ & $-0.220^{* * *}$ \\
\hline Imperfect Score & $\begin{array}{l}0.659 \\
(0.475)\end{array}$ & $\begin{array}{l}0.486 \\
(0.501)\end{array}$ & $0.173^{* * *}$ & $\begin{array}{l}0.457 \\
(0.500)\end{array}$ & $\begin{array}{l}0.189 \\
(0.393)\end{array}$ & $0.268^{* * *}$ & $-0.095^{*}$ \\
\hline \multicolumn{8}{|l|}{ (c) Unit 2} \\
\hline All & $\begin{array}{l}0.268 \\
(0.443)\end{array}$ & $\begin{array}{l}0.213 \\
(0.410)\end{array}$ & $0.055^{* * *}$ & $\begin{array}{l}0.540 \\
(0.499)\end{array}$ & $\begin{array}{l}0.246 \\
(0.431)\end{array}$ & $0.294^{* * *}$ & $-0.239^{* * *}$ \\
\hline Perfect Score & $\begin{array}{l}0.316 \\
(0.465)\end{array}$ & $\begin{array}{l}0.189 \\
(0.392)\end{array}$ & $0.127^{* * *}$ & $\begin{array}{l}0.595 \\
(0.491)\end{array}$ & $\begin{array}{l}0.257 \\
(0.437)\end{array}$ & $0.339^{* * *}$ & $-0.212^{* * *}$ \\
\hline Imperfect Score & $\begin{array}{l}0.220 \\
(0.415)\end{array}$ & $\begin{array}{l}0.236 \\
(0.425)\end{array}$ & -0.016 & $\begin{array}{l}0.425 \\
(0.495)\end{array}$ & $\begin{array}{l}0.229 \\
(0.421)\end{array}$ & $0.197^{* * *}$ & $-0.212^{* * *}$ \\
\hline
\end{tabular}

a) ${ }^{*}$ denotes significant at the $10 \%$ level, ${ }^{* *}$ at the $5 \%$ level, and ${ }^{* * *}$ at the $1 \%$ level. b) Numbers in parentheses are standard deviations. c) In the Vickrey treatments, this table focuses on non-winning bids

(ii) The advice has a negligible effect in mitigating overbidding for the second unit in the Ausubel auction, while it decreases overbidding for the second unit by about $18 \%$ in the Vickrey auction.

(iii) The effect of advice on the rate of sincere bidding for non-winning bids is significantly higher in the Vickrey auction than that in the Ausubel auction.

Support. Table 12 summarizes the non-winning bids in the Vickrey and Ausubel auctions. Support for (i) is provided in Panel (a) of Table 12. We observe that the rates of sincere bidding in AA and VA are $38.9 \%$ and $55 \%$, respectively. Support for (ii) is given by finding the majority bid categories in Table 12 (shown in bold). In Panel (c) for the second unit, the rate of overbidding is nearly equal between AA and AN, while it decreased by about $18 \%$ in the Vickrey treatments. Support for (iii) is given by testing Hypothesis 3', and we have $p<0.001$.

Result 10 shows that the rate of sincere bidding in the Ausubel auction is significantly lower than that in the Vickrey auction when advice is provided, unlike 
Table 11 Frequency of sincere bidding by quiz scores and periods

\begin{tabular}{|c|c|c|c|c|c|c|c|}
\hline & \multicolumn{2}{|c|}{ Ausubel } & \multirow{2}{*}{$\begin{array}{l}(1) \\
A A-A N\end{array}$} & \multicolumn{2}{|l|}{ Vickrey } & \multirow{2}{*}{$\begin{array}{l}\text { (2) } \\
V A-V N\end{array}$} & \multirow{2}{*}{$(1)-(2)$} \\
\hline & AA & AN & & VA & VN & & \\
\hline \multicolumn{8}{|c|}{ (a) Former 13 periods } \\
\hline All & $\begin{array}{l}0.339 \\
(0.474)\end{array}$ & $\begin{array}{l}0.295 \\
(0.456)\end{array}$ & $0.044^{* *}$ & $\begin{array}{l}0.560 \\
(0.497)\end{array}$ & $\begin{array}{l}0.218 \\
(0.413)\end{array}$ & $0.342^{* * *}$ & $-0.298^{* * *}$ \\
\hline Perfect Score & $\begin{array}{l}0.390 \\
(0.488)\end{array}$ & $\begin{array}{l}0.289 \\
(0.454)\end{array}$ & $0.101^{* * *}$ & $\begin{array}{l}0.603 \\
(0.490)\end{array}$ & $\begin{array}{l}0.214 \\
(0.411)\end{array}$ & $0.389^{* * *}$ & $-0.288^{* * *}$ \\
\hline Imperfect Score & $\begin{array}{l}0.284 \\
(0.451)\end{array}$ & $\begin{array}{l}0.300 \\
(0.459)\end{array}$ & -0.016 & $\begin{array}{l}0.459 \\
(0.499)\end{array}$ & $\begin{array}{l}0.223 \\
(0.417)\end{array}$ & $0.237^{* * *}$ & $-0.253^{* * *}$ \\
\hline \multicolumn{8}{|c|}{ (b) Latter 12 periods } \\
\hline All & $\begin{array}{l}0.443 \\
(0.497)\end{array}$ & $\begin{array}{l}0.317 \\
(0.466)\end{array}$ & $0.126^{* * *}$ & $\begin{array}{l}0.540 \\
(0.499)\end{array}$ & $\begin{array}{l}0.264 \\
(0.441)\end{array}$ & $0.275^{* * *}$ & $-0.149^{* * *}$ \\
\hline Perfect Score & $\begin{array}{l}0.470 \\
(0.500)\end{array}$ & $\begin{array}{l}0.302 \\
(0.460)\end{array}$ & $0.168^{* * *}$ & $\begin{array}{l}0.601 \\
(0.490)\end{array}$ & $\begin{array}{l}0.299 \\
(0.458)\end{array}$ & $0.302^{* * *}$ & $-0.134^{* * *}$ \\
\hline Imperfect Score & $\begin{array}{l}0.418 \\
(0.494)\end{array}$ & $\begin{array}{l}0.331 \\
(0.471)\end{array}$ & $0.087^{* * *}$ & $\begin{array}{l}0.407 \\
(0.492)\end{array}$ & $\begin{array}{l}0.208 \\
(0.407)\end{array}$ & $0.199^{* * *}$ & $-0.111^{* *}$ \\
\hline
\end{tabular}

a) ${ }^{*}$ denotes significant at the $10 \%$ level, ${ }^{* *}$ at the $5 \%$ level, and ${ }^{* * *}$ at the $1 \%$ level. b) Numbers in parentheses are standard deviations. c) In the Vickrey treatments, this table focuses on non-winning bids

the case without advice. Moreover, Result 10 suggests that the net advice effect of the Ausubel auction is significantly smaller than that of the Vickrey auction. This may be because the Vickrey auction is strategy-proof, but the Ausubel auction is not. However, considering that our instructions and the statement of advice in the Ausubel auction treatments were designed to be in a similar format as those in our main experiment, this might lead to poor performance of the Ausubel auction. This point is discussed in detail in Sect. 4.7.

We finally test whether quiz scores affect the responsiveness to our advice in the Ausubel auction. The following result demonstrates that a better understanding of the auction rule increases the effect of advice in the Ausubel auction.

Result 11 (Relationship between quiz scores and advice effects) Within the Ausubel auction, the subjects with perfect quiz scores are more responsive to advice than those with imperfect quiz scores. The mean difference between the two groups in terms of an increase in the sincere bidding rate is $9.5 \%$ (95\% confidence interval, $3.4 \%$ to $15.7 \%$ ).

Support. Hypothesis $4^{\prime}$ is rejected at $p<0.001$. 
Table 12 Non-winning bid category by treatments and units

\begin{tabular}{|c|c|c|c|c|c|c|}
\hline \multirow[t]{2}{*}{ Bid category } & \multicolumn{2}{|c|}{ Ausubel } & \multirow[t]{2}{*}{$A A-A N$} & \multicolumn{2}{|l|}{ Vickrey } & \multirow[t]{2}{*}{$\mathrm{VA}-\mathrm{VN}$} \\
\hline & AA & AN & & VA & VN & \\
\hline \multicolumn{7}{|l|}{ (a) Both units } \\
\hline Sincere & $\begin{array}{l}0.389 \\
(0.488)\end{array}$ & $\begin{array}{l}0.305 \\
(0.460)\end{array}$ & $0.084^{* * *}$ & $\begin{array}{l}\mathbf{0 . 5 5 0} \\
(0.498)\end{array}$ & $\begin{array}{l}0.240 \\
(0.427)\end{array}$ & $0.310^{* * *}$ \\
\hline Over & $\begin{array}{l}0.415 \\
(0.493)\end{array}$ & $\begin{array}{l}0.427 \\
(0.495)\end{array}$ & -0.012 & $\begin{array}{l}0.340 \\
(0.474)\end{array}$ & $\begin{array}{l}\mathbf{0 . 5 3 6} \\
(0.499)\end{array}$ & $-0.196^{* * *}$ \\
\hline Under & $\begin{array}{l}0.196 \\
(0.397)\end{array}$ & $\begin{array}{l}0.268 \\
(0.443)\end{array}$ & $-0.072^{* * *}$ & $\begin{array}{l}0.110 \\
(0.312)\end{array}$ & $\begin{array}{l}0.224 \\
(0.417)\end{array}$ & $-0.114^{* * *}$ \\
\hline \multicolumn{7}{|l|}{ (b) Unit 1} \\
\hline Sincere & $\begin{array}{l}\mathbf{0 . 6 7 2} \\
(0.470)\end{array}$ & $\begin{array}{l}\mathbf{0 . 5 1 2} \\
(0.500)\end{array}$ & $0.160^{* * *}$ & $\begin{array}{l}\mathbf{0 . 5 7 3} \\
(0.495)\end{array}$ & $\begin{array}{l}0.226 \\
(0.419)\end{array}$ & $0.347^{* * *}$ \\
\hline Over & $\begin{array}{l}0.145 \\
(0.353)\end{array}$ & $\begin{array}{l}0.195 \\
(0.397)\end{array}$ & $-0.050^{* *}$ & $\begin{array}{l}0.375 \\
(0.485)\end{array}$ & $\begin{array}{l}\mathbf{0 . 5 9 9} \\
(0.491)\end{array}$ & $-0.224^{* * *}$ \\
\hline Under & $\begin{array}{l}0.182 \\
(0.387)\end{array}$ & $\begin{array}{l}0.293 \\
(0.455)\end{array}$ & $-0.110^{* * *}$ & $\begin{array}{l}0.052 \\
(0.222)\end{array}$ & $\begin{array}{l}0.174 \\
(0.380)\end{array}$ & $-0.123^{* * *}$ \\
\hline \multicolumn{7}{|l|}{ (c) Unit 2} \\
\hline Sincere & $\begin{array}{l}0.268 \\
(0.443)\end{array}$ & $\begin{array}{l}0.213 \\
(0.410)\end{array}$ & $0.055^{* * *}$ & $\begin{array}{l}\mathbf{0 . 5 4 0} \\
(0.499)\end{array}$ & $\begin{array}{l}0.246 \\
(0.431)\end{array}$ & $0.294^{* * *}$ \\
\hline Over & $\begin{array}{l}\mathbf{0 . 5 3 0} \\
(0.499)\end{array}$ & $\begin{array}{l}\mathbf{0 . 5 2 9} \\
(0.499)\end{array}$ & 0.001 & $\begin{array}{l}0.325 \\
(0.469)\end{array}$ & $\begin{array}{l}\mathbf{0 . 5 0 8} \\
(0.500)\end{array}$ & $-0.182^{* * *}$ \\
\hline Under & $\begin{array}{l}0.202 \\
(0.402)\end{array}$ & $\begin{array}{l}0.258 \\
(0.438)\end{array}$ & $-0.056^{* * *}$ & $\begin{array}{l}0.135 \\
(0.341)\end{array}$ & $\begin{array}{l}0.246 \\
(0.431)\end{array}$ & $-0.111^{* * *}$ \\
\hline
\end{tabular}

a) ${ }^{*}$ denotes significant at the $10 \%$ level, ${ }^{* *}$ at the $5 \%$ level, and ${ }^{* * *}$ at the $1 \%$ level. b) Numbers in parentheses are standard deviations. c) In the Vickrey treatments, this table focuses on non-winning bids

\subsection{Regression analysis of sincere bidding}

We perform a regression analysis to check the robustness of the results by utilizing a logit model with a random effect at the individual level. Almost all results are confirmed.

Table 13 summarizes the results. In this table, specifications from (13) to (18) jointly clarify how the advice changes sincere bidding behavior for each unit. For the first unit, the advice effect appears as the subjects play repeatedly, regardless of their understanding level of the Ausubel auction. Conversely, specification (18) shows that the advice does not mitigate overbids and underbids for the second unit, as illustrated in Fig. 5.

More interestingly, in the Ausubel auction, the advice effect appears as the subjects play repeatedly only for the first unit (significance and non-significance of Advice $\times$ Latter in specifications (15) and (18) of Table 13, respectively). Meanwhile, in the other auction rules, the impact of Advice $\times$ Latter is insignificant in (3), (6), (9), and (12) of Table 5. This implies that the advice has less impact on sincere bidding for both units in the latter 12 periods. These observations indicate that the advice has a different impact on sincere bidding between units in the latter 
Table 13 Regression analysis of sincere bidding in the Ausubel auction

\begin{tabular}{|c|c|c|c|c|c|c|}
\hline & \multicolumn{3}{|l|}{ Unit 1} & \multicolumn{3}{|l|}{ Unit 2} \\
\hline & (13) & (14) & (15) & (16) & $(17)$ & (18) \\
\hline \multirow[t]{2}{*}{ Advice } & $0.778^{*}$ & 0.436 & 0.113 & 0.338 & 0.341 & 0.121 \\
\hline & $(0.406)$ & $(0.323)$ & $(0.463)$ & $(0.580)$ & $(0.431)$ & $(0.607)$ \\
\hline \multirow[t]{2}{*}{ Perfect Score } & 0.219 & & 0.196 & 0.052 & & 0.018 \\
\hline & $(0.399)$ & & $(0.452)$ & $(0.576)$ & & $(0.602)$ \\
\hline \multirow[t]{2}{*}{ Advice $\times$ Perfect Score } & 0.058 & & 0.598 & 0.467 & & 0.433 \\
\hline & $(0.578)$ & & $(0.653)$ & $(0.820)$ & & $(0.859)$ \\
\hline \multirow[t]{2}{*}{ Latter } & & $0.395^{*}$ & 0.371 & & 0.075 & 0.037 \\
\hline & & $(0.202)$ & $(0.285)$ & & $(0.171)$ & $(0.253)$ \\
\hline \multirow[t]{2}{*}{ Advice $\times$ Latter } & & $0.934^{* * *}$ & $1.456^{* * *}$ & & $0.443^{*}$ & 0.411 \\
\hline & & $(0.306)$ & $(0.441)$ & & $(0.237)$ & $(0.338)$ \\
\hline \multirow[t]{2}{*}{ Latter $\times$ Perfect Score } & & & 0.051 & & & 0.070 \\
\hline & & & $(0.404)$ & & & $(0.343)$ \\
\hline \multirow[t]{2}{*}{ Advice $\times$ Latter $\times$ Perfect Score } & & & $-1.020^{*}$ & & & 0.085 \\
\hline & & & $(0.616)$ & & & $(0.475)$ \\
\hline \multirow[t]{2}{*}{ Constant } & 0.029 & -0.039 & -0.136 & $-2.060^{* * *}$ & $-2.074^{* * *}$ & $-2.079^{* * *}$ \\
\hline & $(0.281)$ & $(0.224)$ & $(0.318)$ & $(0.411)$ & $(0.304)$ & $(0.430)$ \\
\hline Observations & 1,101 & 1,101 & 1,101 & 2,539 & 2,539 & 2,539 \\
\hline Akaike Inf. Crit. & $1,324.765$ & $1,286.744$ & $1,289.184$ & $2,012.186$ & $2,003.285$ & $2,010.236$ \\
\hline
\end{tabular}

a) ${ }^{*}$ denotes significant at the $10 \%$ level, ${ }^{* *}$ at the $5 \%$ level, and ${ }^{* * *}$ at the $1 \%$ level. b) Numbers in parentheses are standard errors

Table 14 Efficiency by treatments and periods in the Ausubel auction

\begin{tabular}{lllll}
\hline Data & AA & AN & $\begin{array}{l}\text { (1) } \\
\text { AA }- \text { AN }\end{array}$ & $(1)-(\mathrm{VA}-\mathrm{VN})$ \\
\hline All periods & 0.986 & 0.982 & $0.005^{*}$ & -0.005 \\
& $(0.050)$ & $(0.054)$ & & \\
Periods 1-13 & 0.981 & 0.975 & 0.006 & -0.009 \\
& $(0.062)$ & $(0.061)$ & & \\
Periods 14-25 & 0.992 & 0.989 & 0.003 & -0.003 \\
& $(0.032)$ & $(0.043)$ & & \\
\hline
\end{tabular}

a) ${ }^{*}$ denotes significant at the $10 \%$ level, ${ }^{* *}$ at the $5 \%$ level, and ${ }^{* * *}$ at the $1 \%$ level. b) Numbers in parentheses are standard deviations. c) In the Vickrey treatments, this table focuses on non-winning bids

12 periods only under the Ausubel auction; that is, the effect of advice on sincere bidding in the Ausubel auction is higher in the latter 12 periods than in the former 13 periods. ${ }^{29}$

\footnotetext{
29 These results hold under logit models without random effects.
} 
Table 15 Average bidder's payoff and average seller's revenue in the Ausubel auction

\begin{tabular}{|c|c|c|c|}
\hline Data & $\mathrm{AA}$ & AN & $A A-A N$ \\
\hline \multicolumn{4}{|c|}{ (a) Bidder's payoff } \\
\hline All periods & $\begin{array}{l}165.711 \\
(218.738)\end{array}$ & $\begin{array}{l}158.007 \\
(212.836)\end{array}$ & 7.704 \\
\hline Period 1-13 & $\begin{array}{l}158.376 \\
(216.427)\end{array}$ & $\begin{array}{l}154.399 \\
(213.467)\end{array}$ & 3.977 \\
\hline Period 14-25 & $\begin{array}{l}173.657 \\
(221.107)\end{array}$ & $\begin{array}{l}162.191 \\
(212.192)\end{array}$ & 11.466 \\
\hline \multicolumn{4}{|c|}{ (b) Seller's revenue } \\
\hline All periods & $\begin{array}{l}1075.111 \\
(354.358)\end{array}$ & $\begin{array}{l}1060.935 \\
(356.833)\end{array}$ & 14.176 \\
\hline Periods $1-13$ & $\begin{array}{l}1095.897 \\
(370.447)\end{array}$ & $\begin{array}{l}1090.283 \\
(343.964)\end{array}$ & 5.614 \\
\hline Periods 14-25 & $\begin{array}{l}1052.593 \\
(335.465)\end{array}$ & $\begin{array}{l}1026.901 \\
(369.092)\end{array}$ & 25.691 \\
\hline
\end{tabular}

a) ${ }^{*}$ denotes significant at the $10 \%$ level, ${ }^{* *}$ at the $5 \%$ level, and ${ }^{* * *}$ at the $1 \%$ level. b) Numbers in parentheses are standard deviations

Table 16 Treatment comparison of seller's revenue and bidders' payoffs

\begin{tabular}{|c|c|c|c|c|c|c|c|c|c|c|}
\hline \multirow[t]{2}{*}{ All periods } & \multicolumn{5}{|c|}{ Seller's revenue } & \multicolumn{5}{|c|}{ Bidders' payoffs } \\
\hline & & PA & PN & $\mathrm{AA}$ & AN & & PA & PN & $\mathrm{AA}$ & AN \\
\hline \multirow[t]{4}{*}{ All periods } & VA & $<* * *$ & $<* * *$ & $>^{* * *}$ & $>^{* * *}$ & VA & $>^{* * *(*)}$ & $>^{* * *}$ (N.Sig.) & $<* * *$ & $<* *$ \\
\hline & VN & $<* * *$ & $<* * *$ & $>^{* *(*)}$ & $>>^{* * *(* *)}$ & VN & $>* * *(* *)$ & $>^{* * *}$ & $<* * *$ & $<* * *$ \\
\hline & PA & & & $>* * *$ & $>* * *$ & PA & & & $<* * *$ & $<* * *$ \\
\hline & PN & & & $>^{* * *}$ & $>^{* * *}$ & PN & & & $<* * *$ & $<* * *$ \\
\hline \multirow[t]{4}{*}{ Periods $1-13$} & VA & $<* * *$ & $<* * *$ & $>*$ (N.Sig.) & $>^{* *(*)}$ & VA & $>* * *$ (N.Sig.) & $>^{* * *}$ (N.Sig.) & $<* *(* * *)$ & $<* *(* * *)$ \\
\hline & VN & $<* * *$ & $<* * *$ & N.Sig. & $>^{*(\text { N.Sig. })}$ & VN & $>* * *(* *)$ & $>^{* * *(* *)}$ & $<* * *$ & $<* * *$ \\
\hline & PA & & & $>^{* * *}$ & $>^{* * *}$ & PA & & & $<* * *$ & $<* * *$ \\
\hline & $\mathrm{PN}$ & & & $>* * *$ & $>^{* * *}$ & $\mathrm{PN}$ & & & $<* * *$ & $<* * *$ \\
\hline \multirow[t]{4}{*}{ Periods 14-25 } & VA & $<^{* * *}$ & $<^{* * *}$ & $>^{* * *(* *)}$ & $>^{* * *}$ & VA & $>* * *(* *)$ & $>^{* * *}$ (N.Sig.) & $<^{* * *}$ & $<* *(* * *)$ \\
\hline & VN & $<* * *$ & $<* * *$ & $>*$ (N.Sig.) & $>^{* *}$ & VN & $>* * *$ (N.Sig.) & $>* * *$ (N.Sig.) & $<* * *$ & $<* * *$ \\
\hline & PA & & & $>* * *$ & $>* * *$ & PA & & & $<* * *$ & $<* * *$ \\
\hline & $\mathrm{PN}$ & & & $>>^{* * *}$ & $>^{* * *}$ & $\mathrm{PN}$ & & & $<* * *$ & $<* * *$ \\
\hline
\end{tabular}

a) * denotes significant at the $10 \%$ level, ${ }^{* *}$ at the $5 \%$ level, and ${ }^{* * *}$ at the $1 \%$ level. b) ">" (or " $<$ ") indicates the treatment in the row (or column) has a larger value. c) We used normal approximation test. d) The star in parenthesis indicates how nonparametric Wilcoxon rank sum test results differ 


\subsection{Efficiency, bidders' payoffs, and seller's revenue}

We first examine the effect of auction rules, advice, and experience on efficiency. We here use the efficiency measure introduced in Sect. 3.5.

Result 12 (Advice effect on efficiency) Providing advice improves efficiency in the Ausubel auction.

Support. Table 14 summarizes the results on efficiency with a focus on experience. In this table, the upper (or middle, bottom) panel collects the results obtained for all periods (periods 1-13 and periods 14-25, respectively). Hypothesis 5' is rejected at the $10 \%$ significant level in all data, while Hypothesis 5 ' is not in the data of periods $1-13(p=0.154)$ and periods $14-25(p=0.224)$.

Through Result 12, we find that, as opposed to the Vickrey auction, the advice effect on efficiency does not appear in the Ausubel auction in early periods.

Thereafter, we ask whether providing advice affects the bidder's payoff in the Ausubel auction. Table 15 summarizes the results on the bidders' payoffs and seller's revenue. We observe that, in the Ausubel auction, the advice does not affect both the bidders' payoffs and the seller's revenue.

Finally, we compare the three auction rules in terms of seller's revenue and bidders' payoffs. Several existing literature shows that the static Vickrey auction yields a higher revenue than the English/Ausubel auction (Kagel et al. 1987 for a single unit sold and Manelli et al. (2006) for multiple units sold). Thus, we determine whether the transparency of dynamic format mitigates overbidding and increases (or decreases) the bidders' payoffs (or the seller's revenue). Table 16 shows the comparison of the seller's revenue and bidders' payoffs across different auction rules. ${ }^{30}$

Given that the valuations of unit 1 are higher than those of unit 2, the overbids in unit 1 , when rejected, often determine the prices in the Vickrey auction. Thus, the more overbids in unit 1 could make the prices higher and bidders' payoffs smaller in the Vickrey auction. This is also true in the Ausubel auction. Panel (b) of Table 12 reports that the overbids in the Vickrey auction are much higher than those in the Ausubel auction in unit 1. This would be the factor of the observations in Table 16 that, when the two auctions are compared, bidders' payoffs in the Vickrey auction are smaller than in the Ausubel auction regardless of whether advice is provided.

Table 6 and Table 14 report that the Vickrey and Ausubel auctions are both almost efficient, implying that both auctions generate almost equal surpluses. Thus, the sellers' revenues in the two auctions are reversed from the bidders' payoffs; that is, the sellers' revenues in the Vickrey auction are larger than those in the Ausubel auction.

\footnotetext{
${ }^{30}$ It is well known that the revenue equivalence result does not generally hold when multiple units are sold (Krishna 2009). In this table, we do not evaluate how close the observed payoffs and revenues are to the predicted ones.
} 
We also observe from Table 16 that the bidders' payoffs in the pay-your-bid auction are less than those in the Vickrey and Ausubel auctions, regardless of whether advice is provided. It is a well-known theoretical result that, in single-object auctions, the bidders' payoffs in the pay-your-bid auction (first-price auction) are less than those in the Vickrey auction when bidders are risk-averse (Holt 1993; Krishna 2009, Ch. 4.2). Table 16 reports similar phenomena in the bidders' payoffs, and the reversed relationships in the sellers' revenues for multi-unit auctions.

\subsection{Comparison with Kagel and Levin (2009)}

In this section, we compare the Ausubel auction experimental data of Kagel and Levin (2009) (hereinafter, KL) and the data of this paper because KL include the Ausubel treatments that resemble our treatments. Among several settings KL used, we focus on the periods wherein subjects were given information feedback and competed for two units, similar to our design. ${ }^{31}$

We carefully deal with the increment of valuation and bid/price to allow a reasonable comparison. Each valuation is drawn from the uniform distribution over $\$ 0$ to $\$ 7.50$ with one cent increment. The price increment is $\$ 0.25$. KL categorize a demand reduction as sincere if the reduction occurred within $\$ 0.125$ of the true valuation.

Based on the KL design detail mentioned previously and our $\$ 0.1 \mathrm{bid} /$ price increment, we redefine sincere bidding in our Ausubel treatments as the demand reduction within $\$ 1.2$ from the true valuation. We denote this category by "KL Sincere." Further, both "KL Over" and "KL Under" are defined accordingly. The bid categories à la KL of our Ausubel treatments are summarized in Table 17. The frequencies of sincere bidding in Table 17 are closer to those observed in the corresponding treatments in KL than in Table 9. However, those frequencies in Table 17 remain lower than each unit in KL.

The lower rate of sincere bidding in Table 17 compared to KL might be partially caused by the difference (to KL) in the instructions. As mentioned in the introduction, our objective in this paper is to examine net advice effects on strategy-proof mechanisms. Therefore, we first focused on the Vickrey auction, which is a wellknown strategy-proof auction rule. To achieve our objective, in our Vickrey and payyour-bid auction treatments, we carefully designed both experimental instructions and the statement of advice in order to minimize the differences among the treatments while avoiding deception. Such design constraints lead to the provision of simple advice. To ensure fair comparison as much as possible, we designed Ausubel auction instructions similar to those in the two static auction rules, and then we provided simple advice in our Ausubel auction treatment. Certainly, the instruction à la $\mathrm{KL}$ and the statement of advice tailored to the Ausubel auction may have increased the rate of sincere bidding. However, we leave this topic for future research.

$\overline{31}$ KL vary the number of bidders in one auction and the number of units sold, within one session. 
Table 17 Comparison with KL Ausubel treatments

\begin{tabular}{llllll}
\hline Bid category & AA & AN & AA - AN & \multicolumn{2}{l}{ KL Ausubel } \\
\cline { 5 - 6 } & & & & Unit 1 & Unit 2 \\
\hline KL Sincere & $69.4 \%$ & $69.6 \%$ & $-0.2 \%$ & $83 \%$ & $77 \%$ \\
KL Over & $24.1 \%$ & $22.9 \%$ & $1.2 \%$ & $5 \%$ & $17 \%$ \\
KL Under & $6.5 \%$ & $7.5 \%$ & $-1.0 \%$ & $12 \%$ & $5 \%$ \\
\hline
\end{tabular}

See Table 2 of Kagel and Levin (2009) for KL Ausubel treatment statistics

\subsection{Nonparametric tests}

Almost pairwise comparison results are consistent with normal approximation tests. Specifically, our nonparametric tests yield the results consistent with Result 2 and Result 9 (see Panel (a) of Table 18), Result 5 and Result 12 (see Panel (e) of Table 18), and Result 7 (see Panels (g) and (h) of Table 18).

\section{Conclusion}

We experimentally demonstrated that introducing advice on strategy-proofness leads to a higher rate of sincere bidding in the multi-unit Vickrey auction. Without this advice, the rate of sincere bidding in our experiment is similar to the rates observed in previous studies. The same piece of advice has effects not only in the Vickrey auction but also in the pay-your-bid auction. The latter effect is attributed to the socalled experimenter demand effect (Zizzo 2009). To determine whether the advice has an effect beyond the experimenter demand effect, which we call the net advice effect, we compared the effects in the two auctions. The results indicate that a substantial net advice effect exists in the Vickrey auction.

Considering that overbidding in the Vickrey auction has been widely observed in the literature (Kagel and Levin 1993; Garratt et al. 2012; Engelmann and Grimm 2009; Porter and Vragov 2006), researchers have attempted to identify factors that drive overbidding, such as the anticipation of regret, the joy of winning (Cooper and Fang 2008), cognitive limits on contingent reasoning ( $\mathrm{Li} 2017$ ), and underestimation of possible losses (Georganas et al. 2017). Our results suggest that one of the key drivers of overbidding is the subjects' failure to grasp the strategy-proofness of the Vickrey auction, despite the fact that the subjects perfectly understand the procedure of the Vickrey auction.

Note that our statement of advice is relatively simple to ensure that the same advice can be used in the two auctions. This simplicity makes the effect of advice limited. However, even such simple advice has a considerable net advice effect in the Vickrey auction. Further, more detailed advice would make the subjects bid more sincerely. 


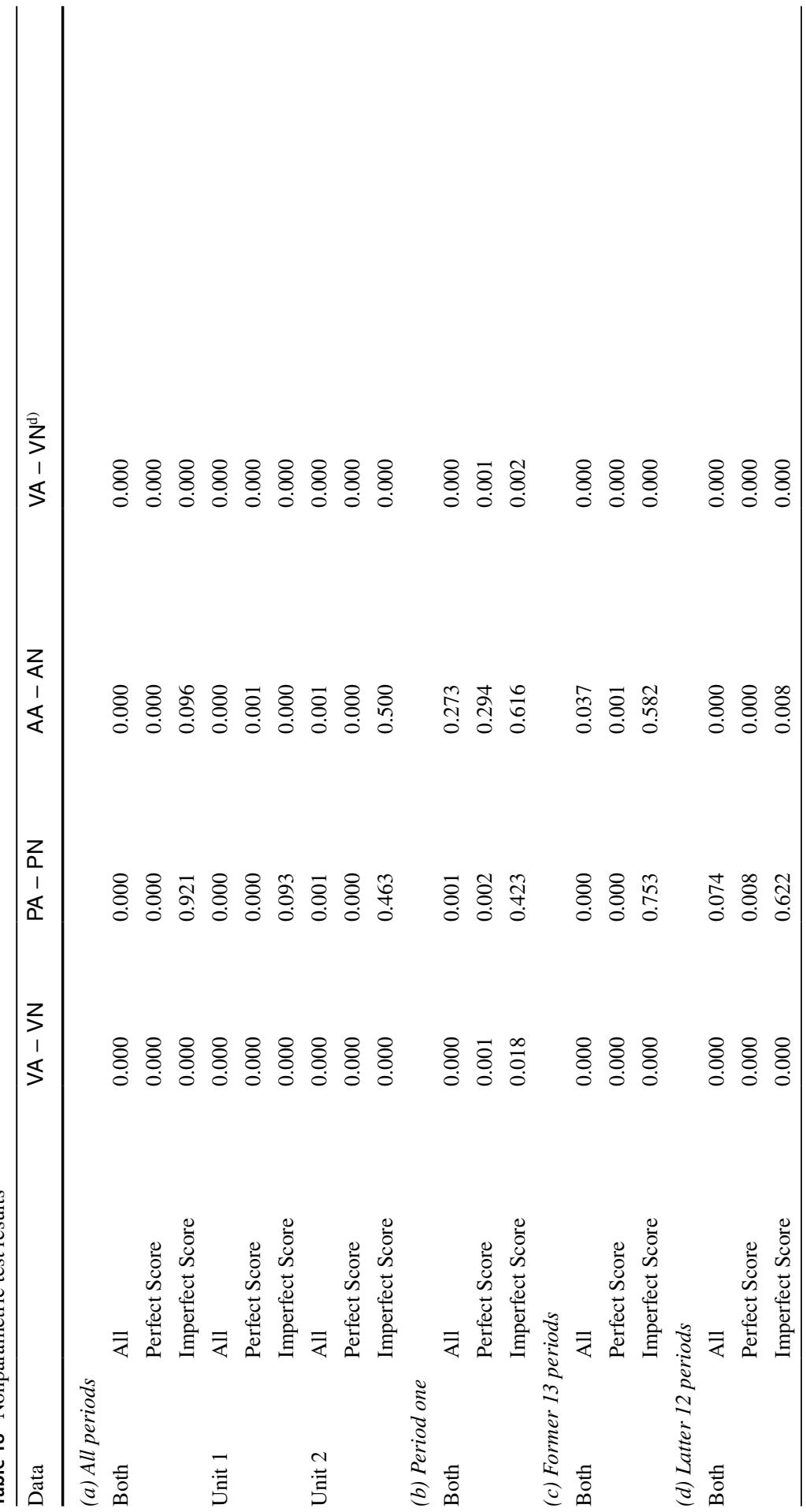




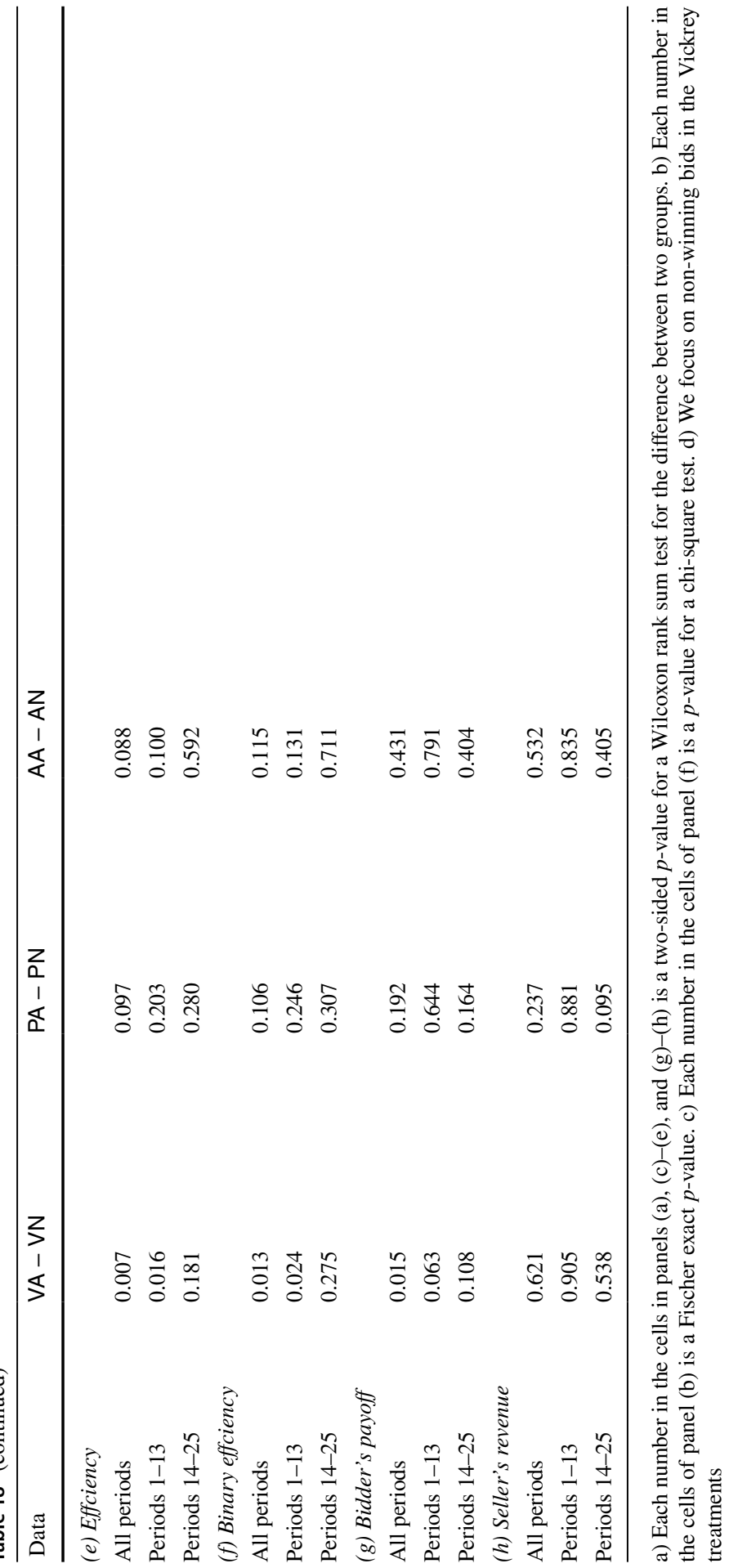


Our results indicate that simple advice improves efficiency in the Vickrey auction. This improvement is higher in early periods, when subjects are less experienced. Thus, our results demonstrate that advice improves efficiency in the Vickrey auction by promoting a better understanding of the strategy-proofness of the Vickrey auction.

To focus on the advice effect on bidding behavior, we conducted experiments in a "symmetric" environment, that is, an environment wherein each bidder in the same auction has the same distribution function of valuations. As discussed in Sect. 3.5, the pay-your-bid auction and the Vickrey auction generated almost perfectly efficient outcomes in such a symmetric environment. Thus, even without advice, efficiency in both auctions has little room for improvement. That is, in our experiment, the effects of advice on efficiency are limited in both auctions. We conjecture that experiments in an "asymmetric" environment would clarify the advice effect on efficiency.

Supplementary Information The online version contains supplementary material available at https://doi. org/10.1007/s10683-021-09736-5.

Acknowledgements We are grateful to John Duffy, the editor of this journal, and two anonymous referees for their useful comments and suggestions that helped us to improve the paper. We thank Yoshitaka Okano for providing the z-Tree program of the Ausubel auction and the very helpful discussion. We also thank Kou Fujimori, Pablo Guillen, Nobuyuki Hanaki, Naoko Nishimura, Hans-Theo Normann, Alvin Roth, Tayfun Sönmez, Utku Ünver, Takashi Yamagata, and Lianming Zhu for their helpful comments. Yuki Hamada provided excellent research assistance. We gratefully acknowledge the financial support from the Joint Usage/Research Center at ISER, Osaka University; Osaka University's International Joint Research Promotion Program (Type A); and Grant-in-aid for Research Activity, Japan Society for the Promotion of Science (15H05728, 20H05631, 20K01555, 20KK0027).

Funding We gratefully acknowledge the financial support from the Joint Usage/Research Center at ISER, Osaka University; Osaka University's International Joint Research Promotion Program (Type A); and Grant-in-aid for Research Activity, Japan Society for the Promotion of Science (15H05728, 20H05631, 20K01555, 20KK0027).

\section{Declarations}

Conflicts of interest The authors declare that they have no conflict of interest.

Availability of data and material Data are available at the journal's website.

Code availability Code used in analysis is available at the journal's website.

Open Access This article is licensed under a Creative Commons Attribution 4.0 International License, which permits use, sharing, adaptation, distribution and reproduction in any medium or format, as long as you give appropriate credit to the original author(s) and the source, provide a link to the Creative Commons licence, and indicate if changes were made. The images or other third party material in this article are included in the article's Creative Commons licence, unless indicated otherwise in a credit line to the material. If material is not included in the article's Creative Commons licence and your intended use is not permitted by statutory regulation or exceeds the permitted use, you will need to obtain permission directly from the copyright holder. To view a copy of this licence, visit http://creativecommons.org/licenses/by/4.0/. 


\section{References}

Abdulkadiroğlu, A., \& Sönmez, T. (2003). School choice: A mechanism design approach. American Economic Review, 93, 729-747.

Angrist, J. D., \& Pischke, J. S. (2008). Mostly harmless econometrics: An empiricists companion. New Jersey: Princeton University Press.

Attiyeh, G., Franciosi, R., \& Isaac, R. M. (2000). Experiments with the pivotal process for providing public goods. Public Choice, 102, 95-114.

Ausubel, L. (2004). An efficient ascending-bid auction for multiple objects. American Economic Review, 94, 1452-1475.

Baisa, B. (2020). Efficient multiunit auctions for normal goods. Theoretical Economics, 15, 361-413.

Breitmoser, Y., \& Schweighofer-Kodritsch, S. (2021). Obviousness around the clock. Forthcoming in Experimental Economics.

Brenner, M., Galai, D., \& Sade, O. (2009). Sovereign debt auctions: Uniform or discriminatory? Journal of Monetary Economics, 56, 267-274.

Cason, T., Saijo, T., Sjöström, T., \& Yamato, T. (2006). Secure implementation experiments: Do strategyproof mechanisms really work? Games and Economic Behavior, 57, 206-235.

Chen, Y., \& Sönmez, T. (2006). School choice: An experimental study. Journal of Economic Theory, 127, 202-231.

Cooper, D. J., \& Fang, H. (2008). Understanding overbidding in second price auctions: An experimental study. Economic Journal, 118, 1572-1595.

Ding, T., \& Schotter, A. (2017). Matching and chatting: An experimental study of the impact of network communication on school-matching mechanisms. Games and Economic Behavior, 103, 94-115.

Ding, T., \& Schotter, A. (2019). Learning and mechanism design: An experimental test of school matching mechanisms with intergenerational advice. Economic Journal, 129, 2779-2804.

Engelmann, D., \& Grimm, V. (2009). Bidding behavior in multi-unit auctions: An experimental investigation and some theoretical insights. Economic Journal, 119, 855-882.

Fischbacher, U. (2007). z-Tree: Zurich toolbox for readymade economic experiments. Experimental Economics, 10, 171-178.

Garratt, R. J., Walker, M., \& Wooders, J. (2012). Behavior in second-price auctions by highly experienced eBay buyers and sellers. Experimental Economics, 15, 44-57.

Georganas, S., Levin, D., \& McGee, P. (2017). Optimistic irrationality and overbidding in private value auctions. Experimental Economics, 20, 772-792.

Grether, D., \& Plott, C. (1979). Economic theory of choice and the preference reversal phenomenon. American Economic Review, 69, 623-638.

Guillen, P., \& Hakimov, R. (2017). Not quite the best response: Truth-telling, strategy-proof matching, and the manipulation of others. Experimental Economics, 20, 670-686.

Guillen, P., \& Hakimov, R. (2018). The effectiveness of top-down advice in strategy-proof mechanisms: A field experiment. European Economic Review, 101, 505-511.

Guillen, P., \& Hing, A. (2014). Lying through their teeth: Third party advice and truth telling in a strategy proof mechanism. European Economic Review, 70, 178-185.

Hanaki, N., Jacquemet, N., Luchini, S., \& Zylbersztejn, A. (2016). Cognitive ability and the effect of strategic uncertainty. Theory and Decision, 81, 101-121.

Hassidim, A., Marciano, D., Romm, A., \& Shorrer, R. I. (2017). The mechanism is truthful, why arent you? American Economic Review, 107, 220-224.

Harstad, R. M. (2000). Dominant strategy adoption and bidders experience with pricing rules. Experimental economics, 3, 261-280.

Holmström, B. (1979). Groves scheme on restricted domains. Econometrica, 47, 1137-1144.

Holt, C. (1993). Competitive bidding for contracts under alternative auction procedures. Journal of Political Economy, 88, 433-445.

Jacquemet, N., \& Lharidon, O. (2018). Experimental economics: Method and applications. Cambridge: Cambridge University Press.

Kagel, J. H., Harstad, R., \& Levin, D. (1987). Information impact and allocation rules in auctions with affiliated private values: A laboratory study. Econometrica, 55, 1275-1304.

Kagel, J. H., \& Levin, D. (1993). Independent private value auctions: Bidder behaviour in first-, secondand third-price auctions with varying numbers of bidders. Economic Journal, 103, 868-879. 
Kagel, J. H., \& Levin, D. (2001). Behavior in multi-unit demand auctions: Experiments with uniform price and dynamic Vickrey auctions. Econometrica, 69, 413-454.

Kagel, J. H., \& Levin, D. (2009). Implementing efficient multi-object auction institutions: An experimental study of the performance of boundedly rational agents. Games and Economic Behavior, 66, 221-237.

Kagel, J. H., \& Levin, D. (2016). Auctions: A survey of experimental research. In J. H. Kagel \& A. E. Roth (Eds.), Handbook of Experimental Economics (Vol. 2). New Jersey: Princeton University Press.

Kawagoe, T., \& Mori, T. (2001). Can the pivotal mechanism induce truth-telling? An experimental study. Public Choice, 108, 331-354.

Krishna, V. (2009). Auction theory (2nd ed.). Cambridge: Academic Press.

Kwasnica, A. M., \& Sherstyuk, K. (2013). Multiunit auctions. Journal of Economic Surveys, 27, 461-490.

Lebrun, B., \& Tremblay, M.-C. (2003). Multiunit pay-your-bid auction with one-dimensional multiunit demands. International Economic Review, 44, 1135-1172.

Li, S. (2017). Obviously strategy-proof mechanisms. American Economic Review, 107, 3257-3287.

List, J. A. (2001). Do explicit warnings eliminate the hypothetical bias in elicitation procedures? Evidence from field auctions for sportscards. American Economic Review, 91, 1498-1507.

Manelli, A. M., Sefton, M., \& Wilner, B. (2006). Multi-unit auctions: A comparison of static and dynamic mechanisms. Journal of Economic Behavior and Organization, 61, 304-323.

Marszalec, D. (2017). The impact of auction choice on revenue in treasury bill auctions-An empirical evaluation. International Journal of Industrial Organization, 53, 215-239.

McGee, P., \& Levin, D. (2019). How obvious is the dominant strategy in an English auction? Experimental evidence. Journal of Economic Behavior and Organization, 159, 355-365.

Milgrom, P. (2000). Putting auction theory to work: The simultaneous ascending auction. Journal of Political Economy, 108, 245-272.

Okamoto, N. (2018). An efficient ascending-bid auction for multiple objects: Comment. American Economic Review, 108, 555-560.

Porter, D., \& Vragov, R. (2006). An experimental examination of demand reduction in multi-unit versions of the Uniform-price, Vickrey, and English auctions. Managerial and Decision Economics, 27, 445-458.

Roth, A. E., Sömez, T., \& Ünver, M. (2004). Kidney exchange. Quarterly Journal of Economics, 119, 457-488.

Saijo, T., Sjöström, T., \& Yamato, T. (2007). Secure implementation. Theoretical Economics, 2, $203-229$.

Shogren, J. F., Margolis, M., Koo, C., \& List, J. A. (2001). A random nth-price auction. Journal of Economic Behavior and Organization, 46, 409-421.

Velez, R. A., \& Brown, A. L. (2020). Empirical strategy-proofness. Mimeo.

Vickrey, W. (1961). Counterspeculation, auctions, and competitive sealed tenders. Journal of Finance, 16, 8-37.

Zizzo, D. J. (2009). Experimenter demand effects in economic experiments. Experimental Economics, $13,75-98$.

Publisher's Note Springer Nature remains neutral with regard to jurisdictional claims in published maps and institutional affiliations. 


\section{Authors and Affiliations}

Takehito Masuda ${ }^{1} \cdot$ Ryo Mikami ${ }^{2} \cdot$ Toyotaka Sakai $^{3} \cdot$ Shigehiro Serizawa ${ }^{2}$. Takuma Wakayama ${ }^{4}$

Takehito Masuda

tmasuda@shinshu-u.ac.jp

Ryo Mikami

ryomyself@gmail.com

Toyotaka Sakai

tsakai@z5.keio.jp

Shigehiro Serizawa

serizawa@iser.osaka-u.ac.jp

1 Faculty of Economics and Law, Shinshu University, Nagano 390-8621, Japan

2 ISER, Osaka University, Osaka 567-0047, Japan

3 Department of Economics, Keio University, Tokyo 108-8345, Japan

4 Faculty of Economics, Ryukoku University, Kyoto 612-8577, Japan 